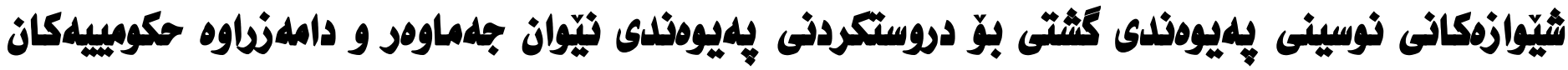

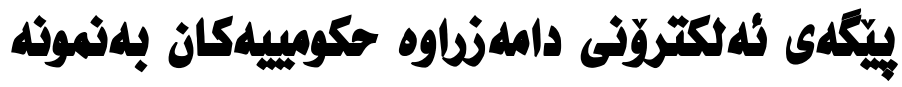

\section{شوّخان أبوبكر على}

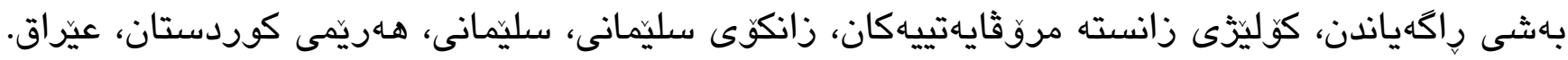
shokhan.ali@univsul.edu.iq ئيمهيل

קوخته:

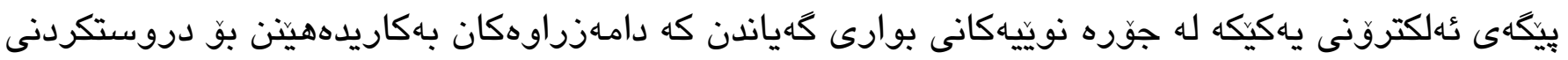

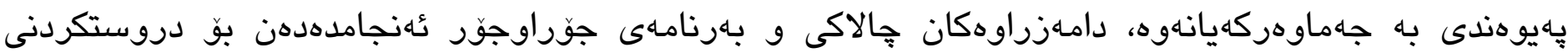

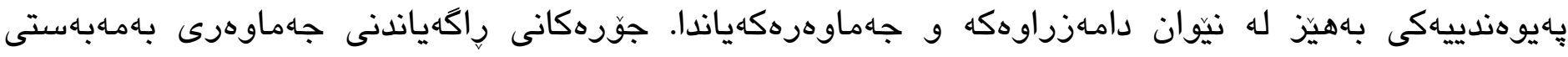
ناساندنى كار و جِالاكييهكانيان بوّ زوّرترين جهماوهر بهكاردهينين، ناونيشانى ئهم تويَّينهوهيه (شيّوازهكانى

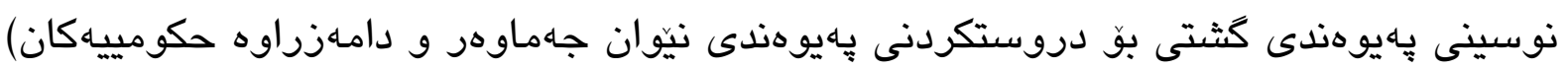

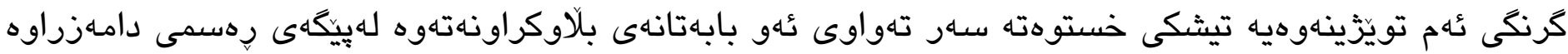
حكومييهكان و شهانوكهوكردنى بابهتهانى و شيكردنهوهى سهرجهم لايهنهانى بهمابهاستى زانينى جوّنيتى نووسينى بابهتهكان و زانينى تهواوى ئهو جالاكيانهى دامهزراوهكان ئهنجامى دهدهن، بيّويسته هـهو دامهزراوهكان

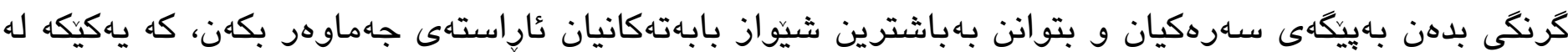
كرنكترين بازنهانى يهيوهندى نيّوان دامهزراوه حكومييهكان و جهماوهرى ناوخق و دهرهوه.

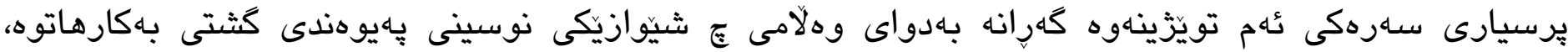
كاروجالاكى دامهزراوه حكومييهكان له ع بواريكدايه و كامانهن. ئامانجى تويّزينهوهكه بو خستنهروى ئهو شيّواز و زانرانهى نوسينى بهايوهندى كَثتيه كه زياتر بهكارهاتوه،

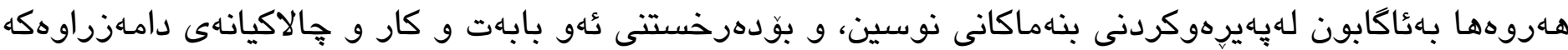

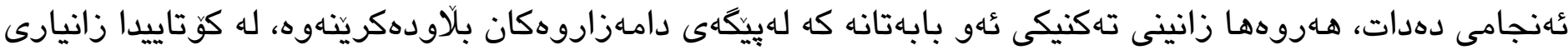

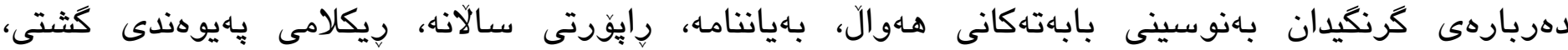
كؤروكوَيوناوه، يِيشانكا و كونفرانس. 


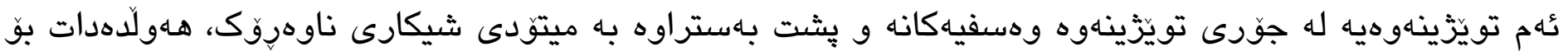

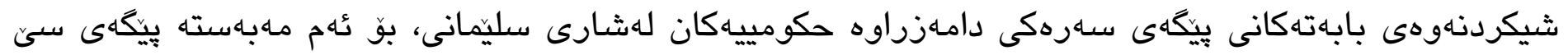

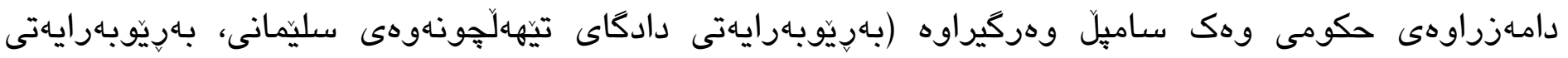

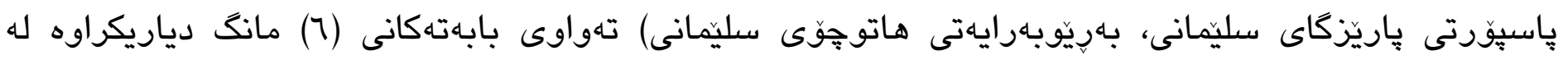

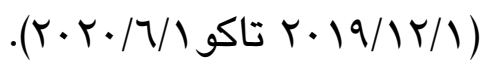

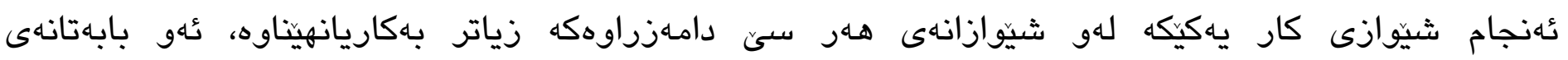

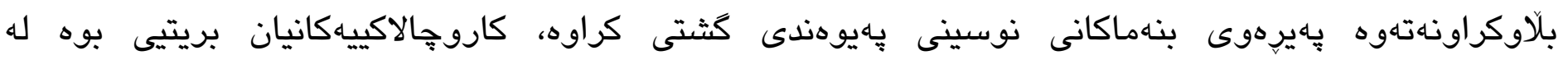

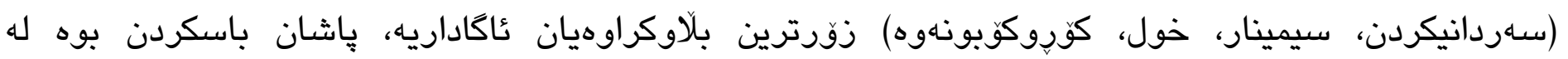

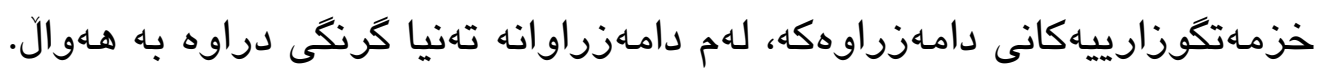

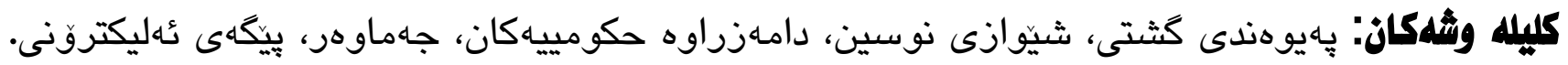

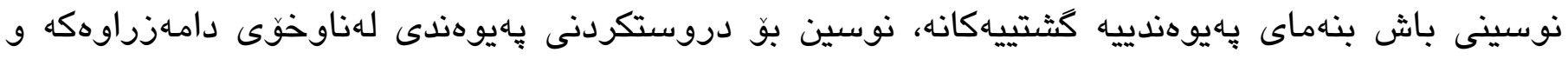

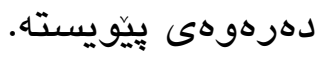

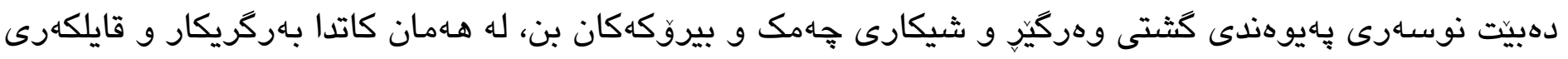

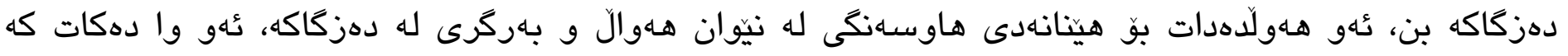

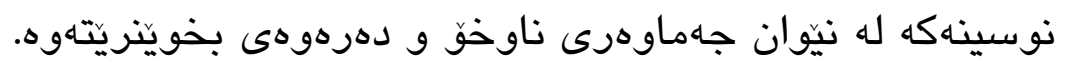

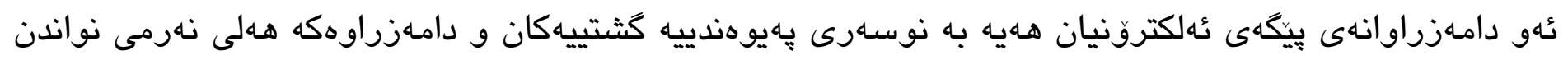

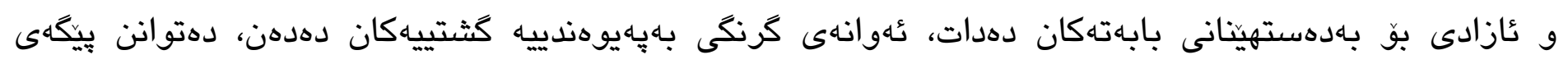

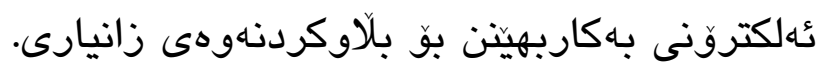

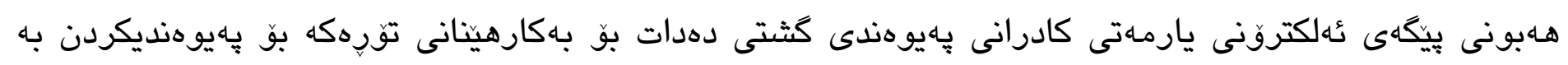

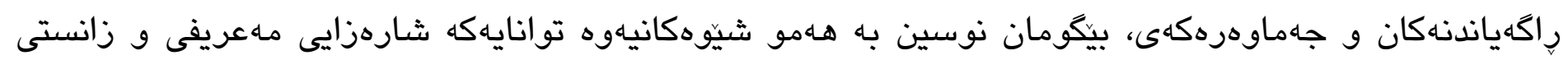
يِيّويسته.

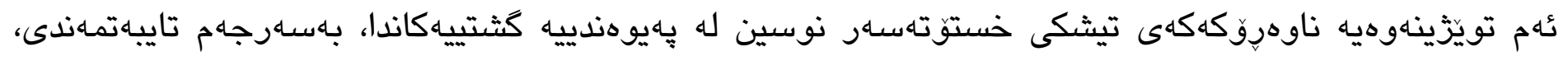

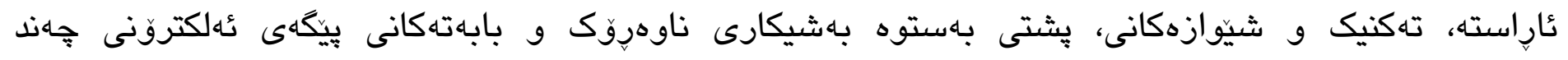

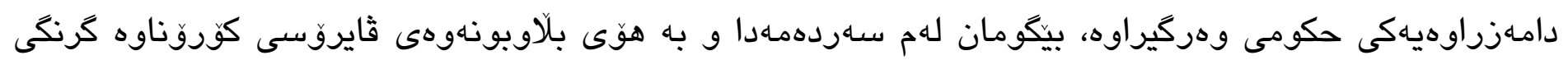




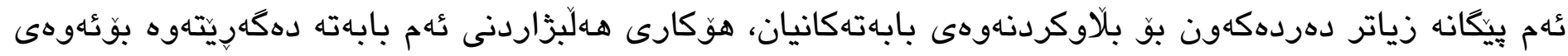

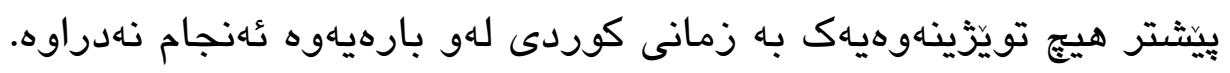

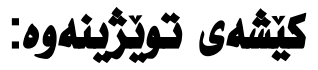

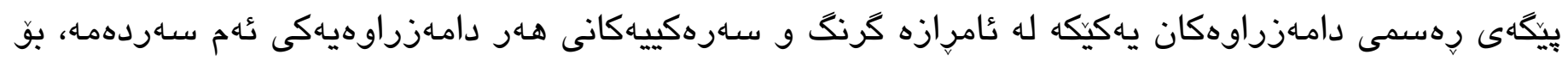

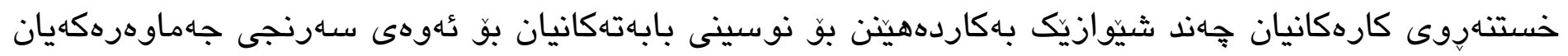

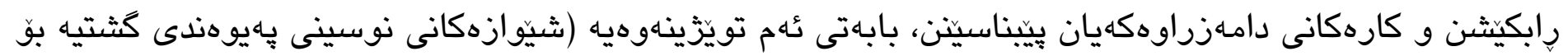
دروستكردنى نيّوان جهاوهرو دامـزراوه حكومييهكان) دروستبونى يرسياره له بارهى نازانريّ جِّن نوسينى

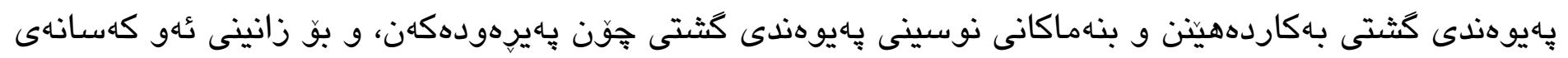

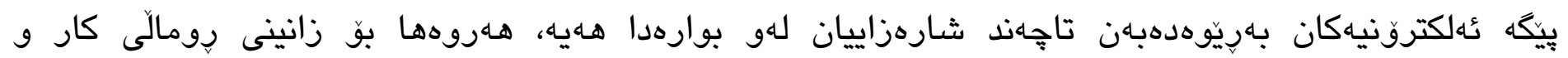

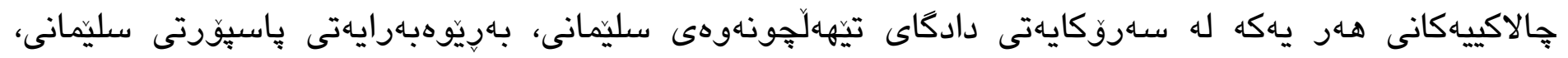

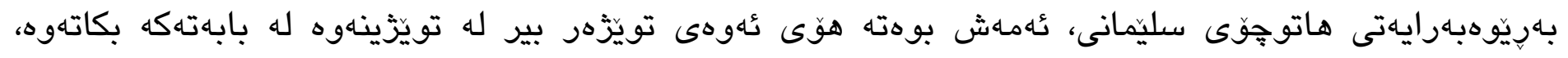

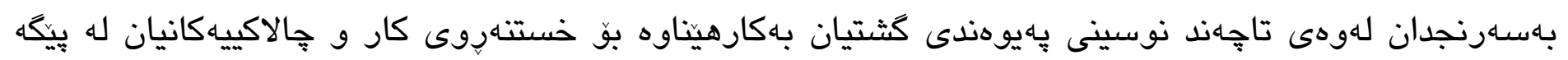
رهسمييهكانى خوّياندا.

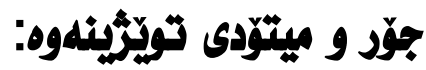

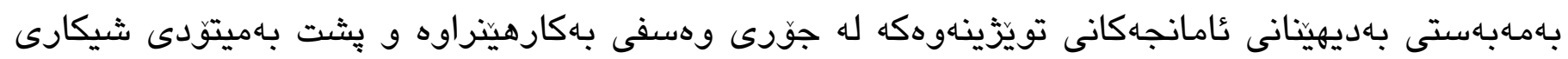

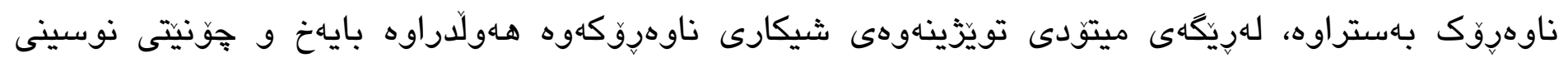
يهيوهندى كُثتى بزانريت، شيكارى ناوهروك ئهو ميتودهيه كه زياتر له بوارى راكهياندندا بهكاردهينِريّت و

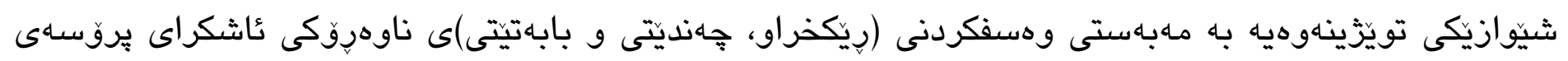

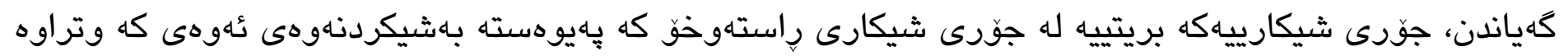

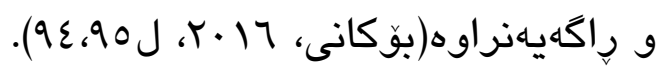

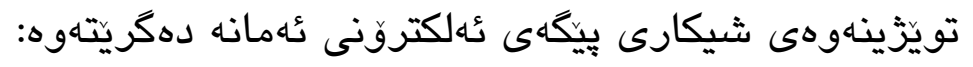
I. شيكردنهوهى دهق و عامرازى يِيشاندان و يِيشكهشكردن.

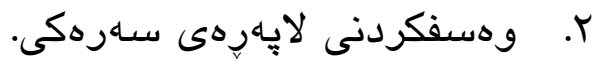

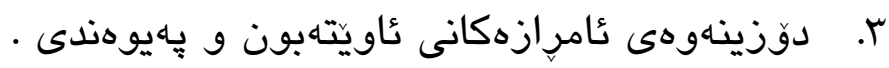
ع. شيكارى خزمهتكوزارييهكانى رِاكهياندن.

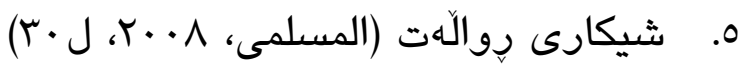




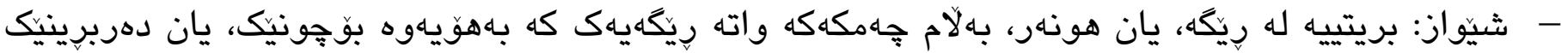
دهردهبردريّت، واته دهربرين به شيّوهيهكى زارهكى بو سيستهمى قسهردن، يان واتاكان، شيّوازيش سيّ

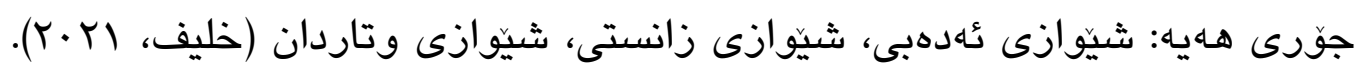

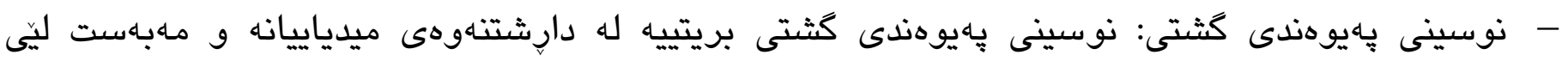

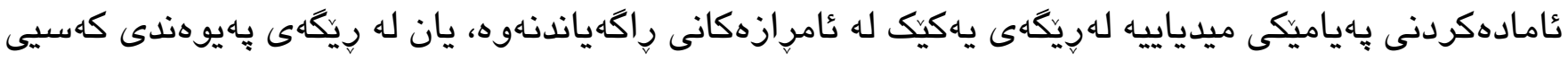
راستهوخووه ئاراستهى جهماوهر دهكيّت، به ئامانجى كَهاندنى راستييهكان بهجهماوهر، هـروهها

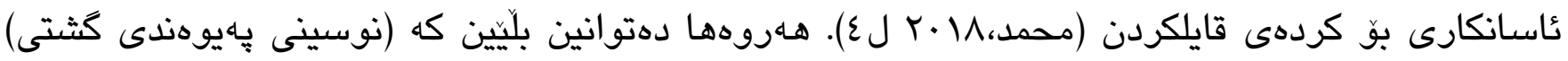

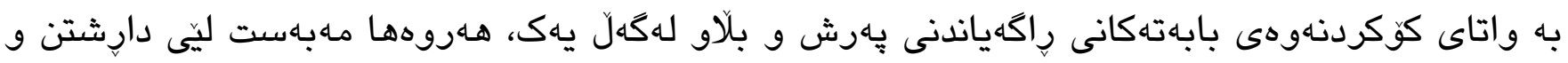

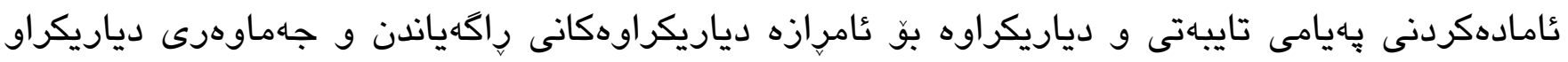

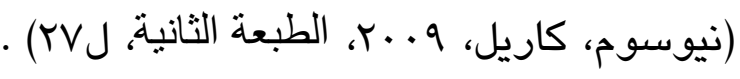

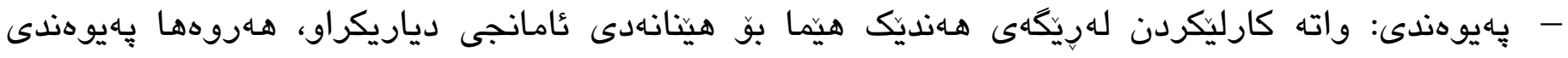

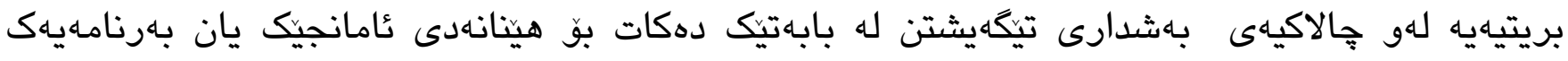

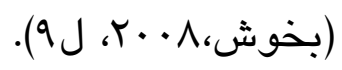

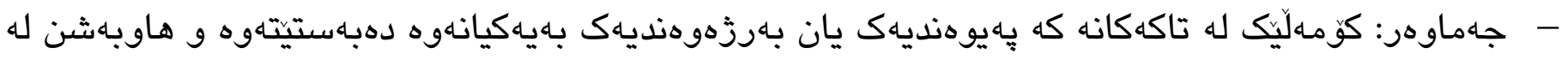

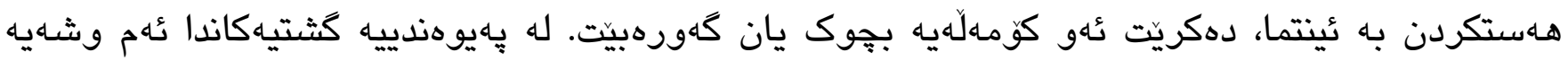

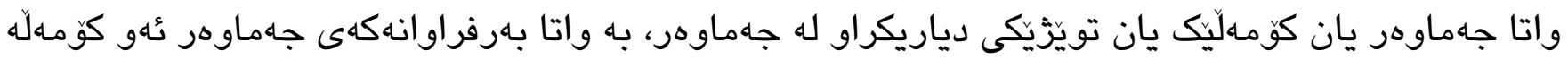

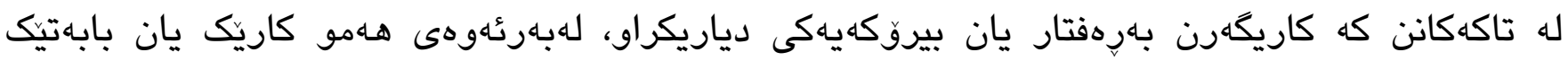

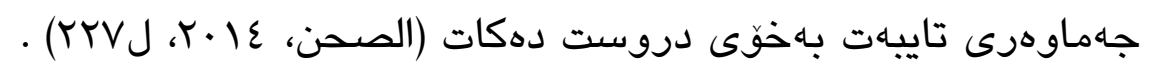

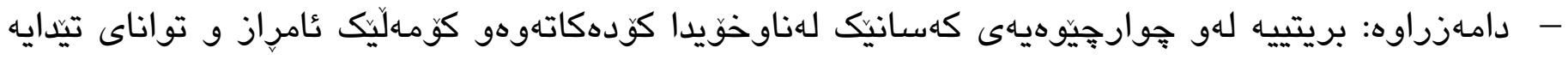

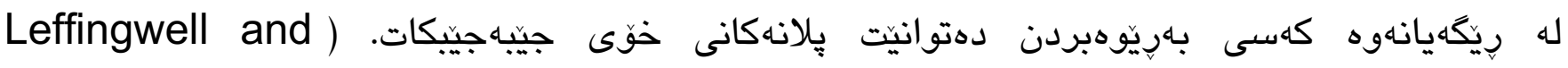
(Robinsonp, 1980, 53 - دامهزراوهى حكومى: خاوهنداريتى ئهم دامهزراوانه دهكَرِيتّهوه بوّ دهولّه، دهولّهت خوّى سهارمايهى

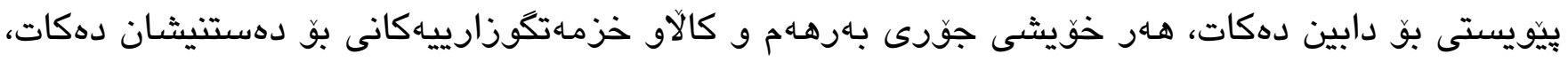

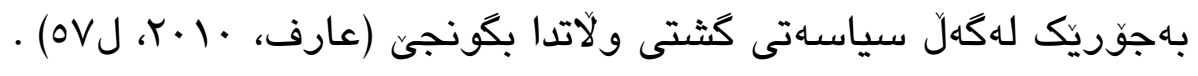




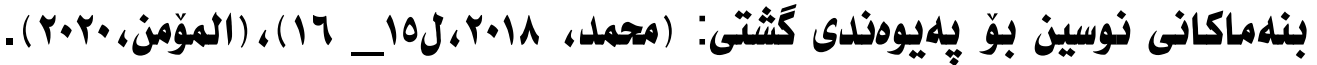

مهابهست له بنهماكان واته ئهو ريّسايانهيه كه له نوسينيكدا يهيرهودهكيّيت، دواى شيكردنهوه و دهربرينى بيروكهكه پِاشان بكريت به نوسين و ناراستهى جهماوهرى مـابهتدار بكريت، دهتوانين ئهو بنهمايانه لهم جههند خالّى خوارهوهدا دياريبكرين:

ا. رِونى: دوركهوتنهوه لهو وشه و دهستهوازانهى باو نين، بيروّكهه به وردى دياريبكريت، نوسهار به يهك

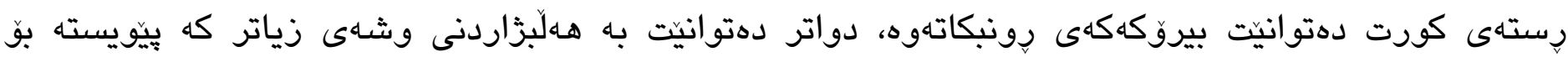

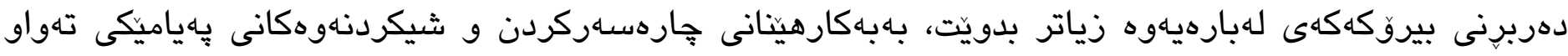
دهنوسريّت

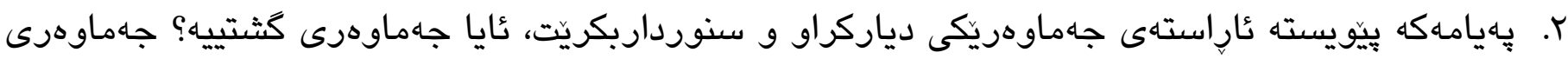

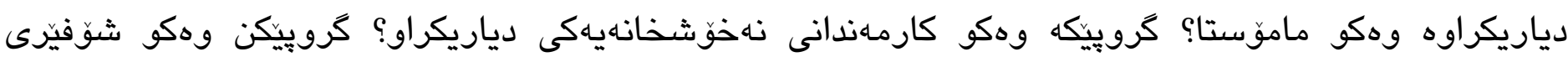

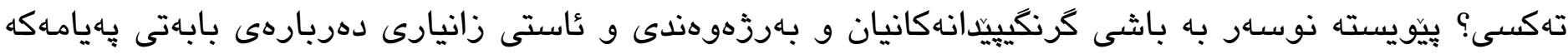

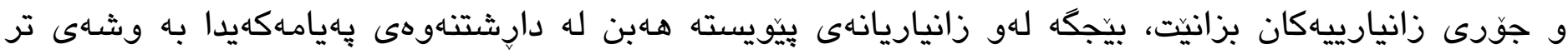

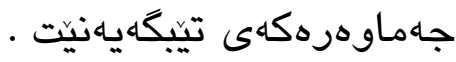

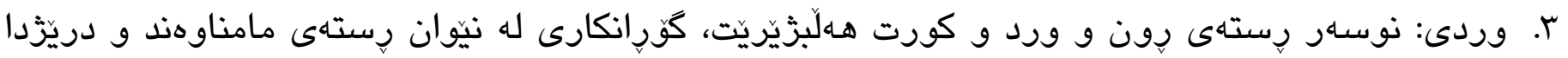

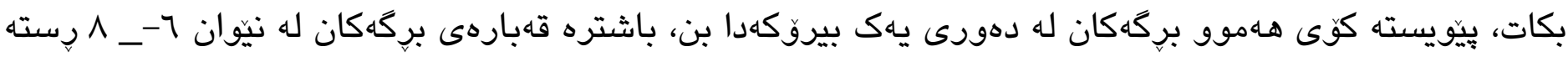
بن، هينده ئاسان بيت بو خوينهار بتوانيت بيخوينيتيتهوه و لييتيَيكات.

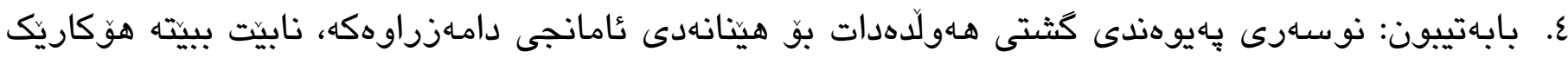

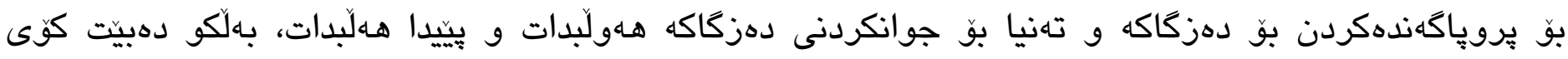

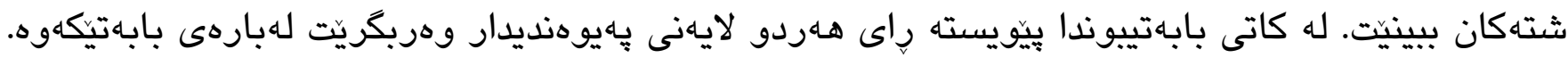

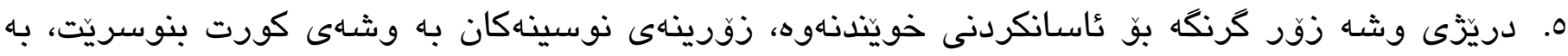

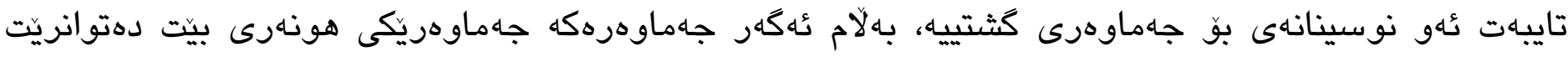

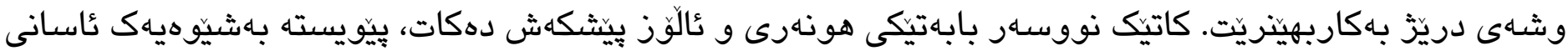

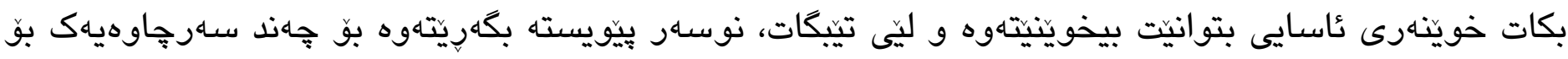

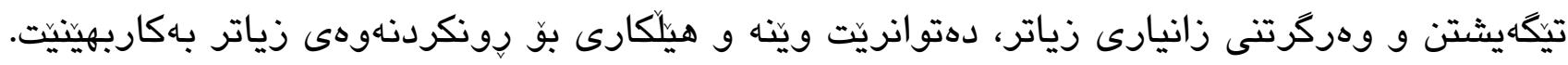

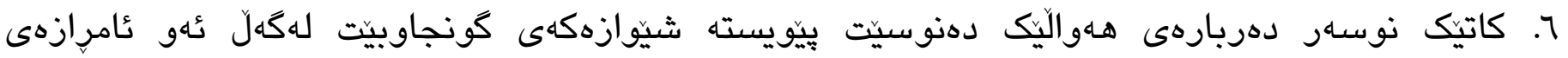

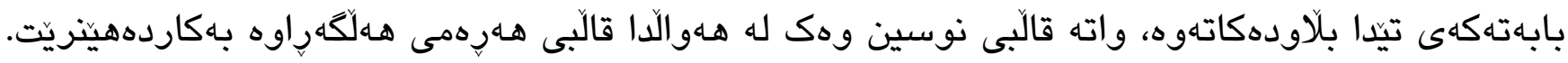




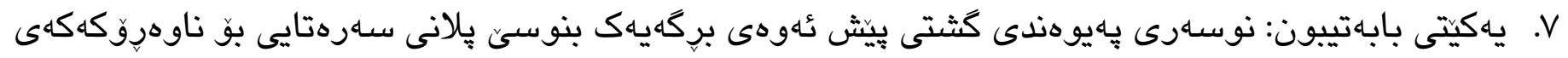

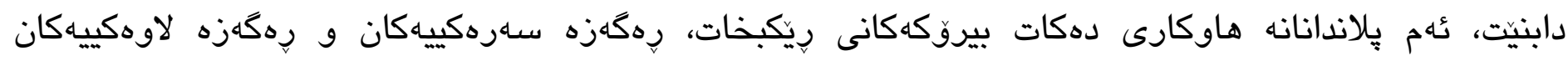

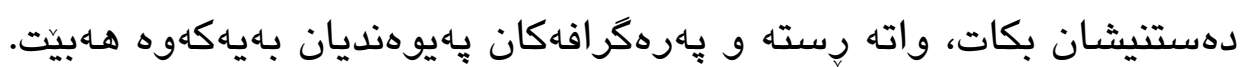

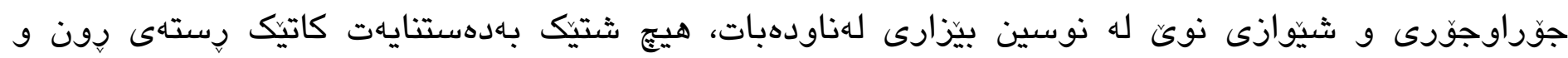

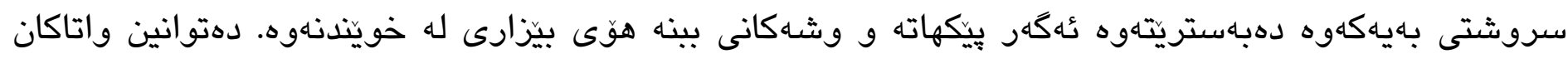

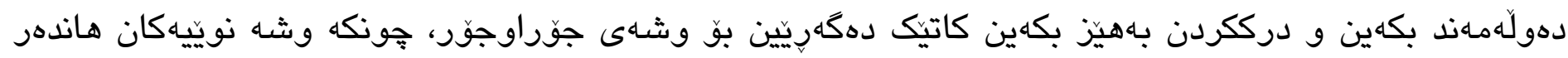

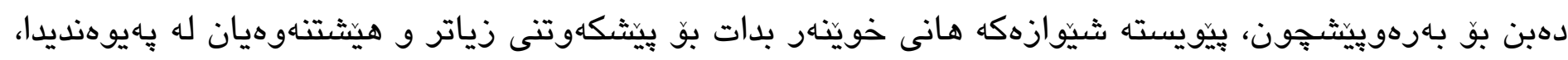

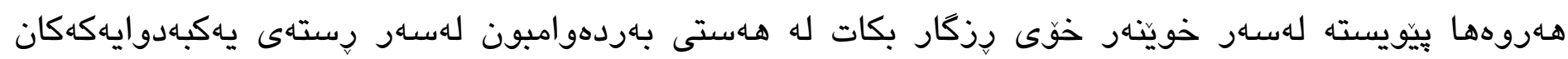

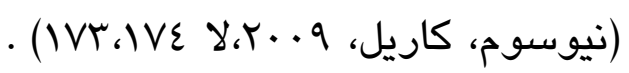

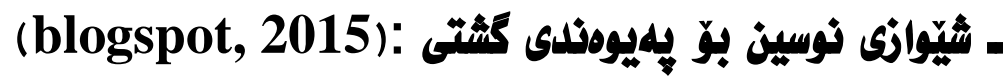

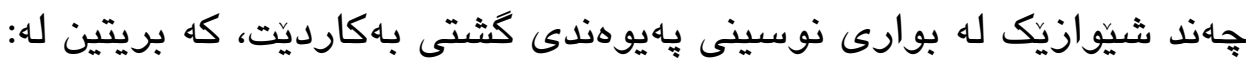

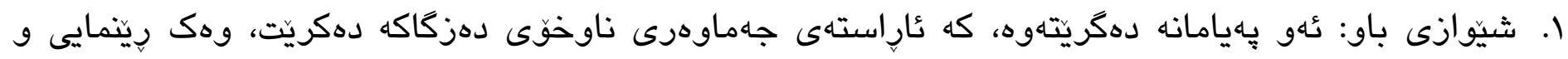

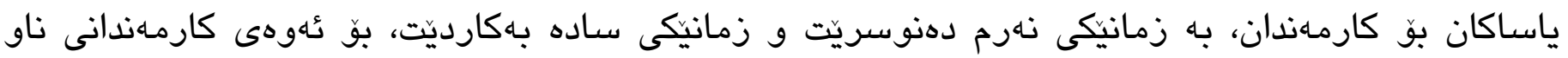

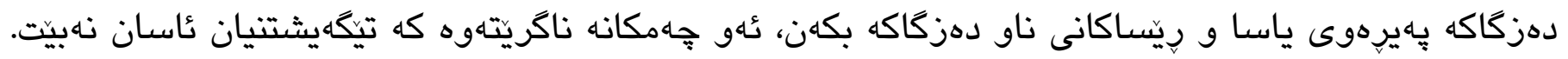

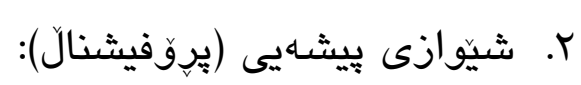

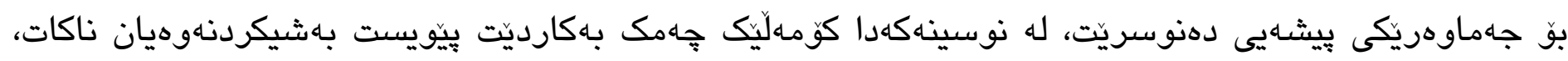

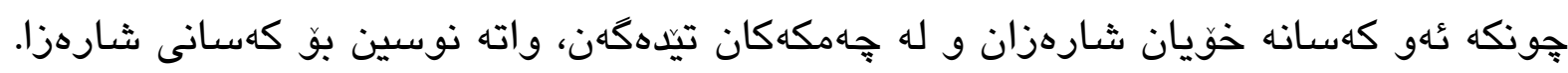

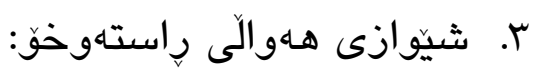

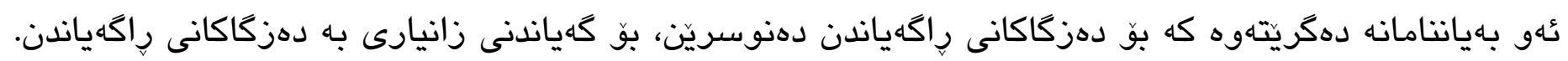

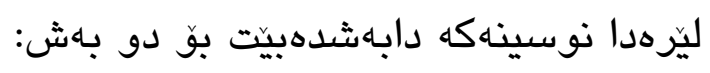

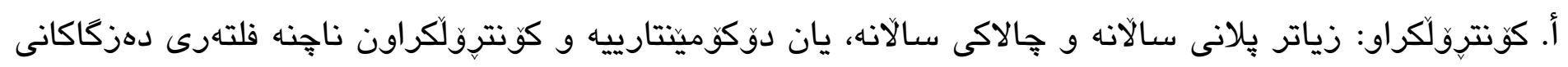

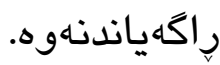

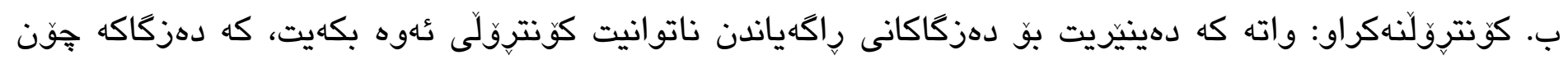

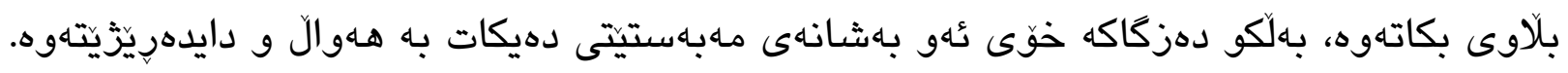

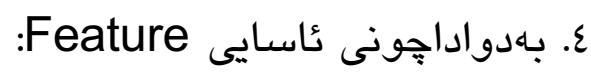

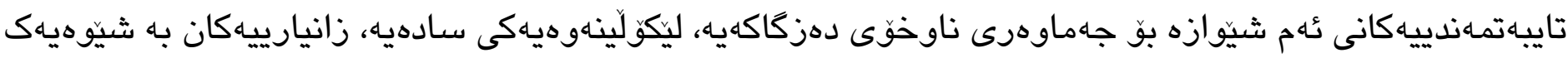

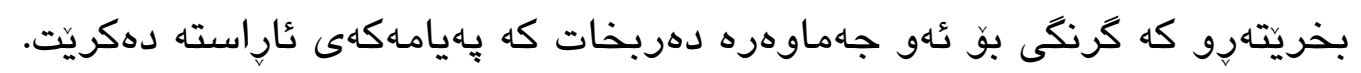
255 


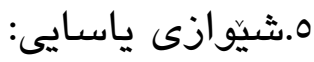

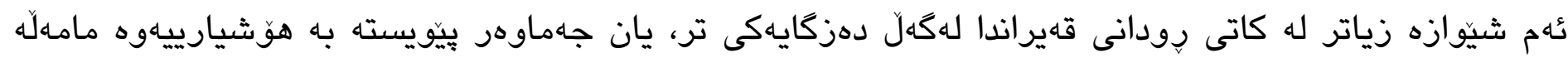
بكريتّ.

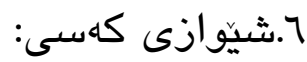
له نيّوان دو كهس بهكارديّت كه ئاستى بهريرسياريتيان له يهكهوه نزيكبيت، يان وهك يهكبن، بو نمونه له بهريّوهبهرى دهزكايهكهوه بوّ بهاريّوهبهرى دهزكايهكى تر.

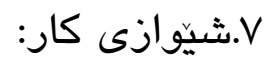

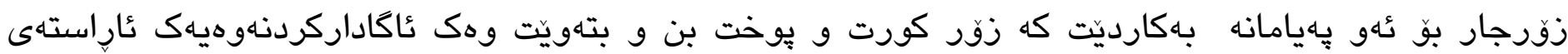
جهماوهر بكريت.

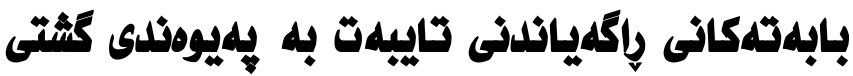

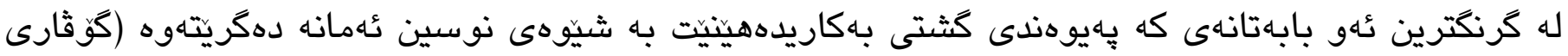

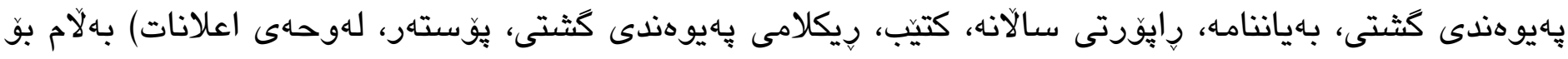

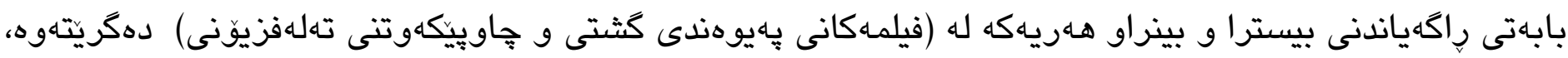

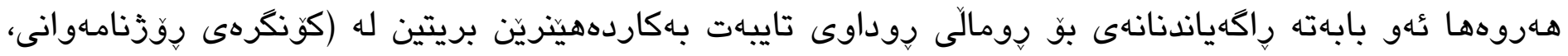

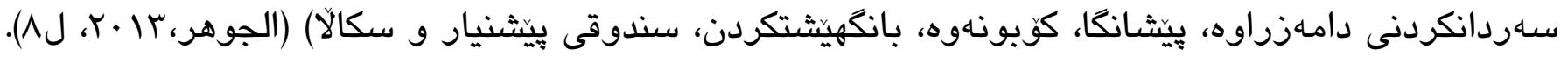

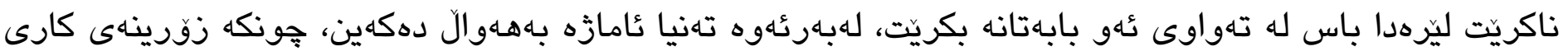

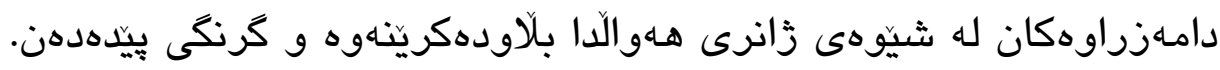

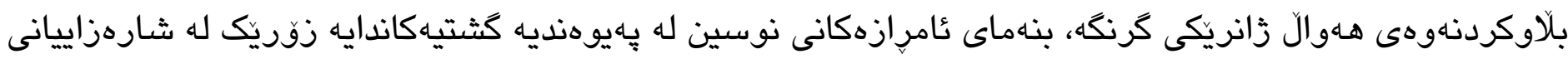

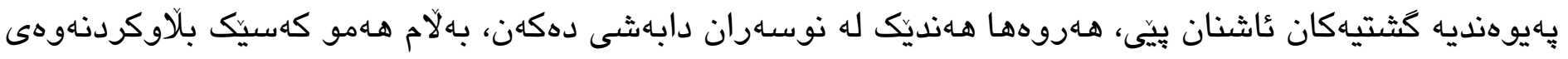

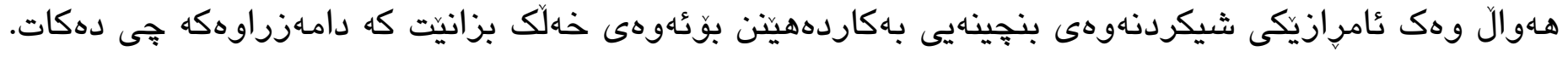




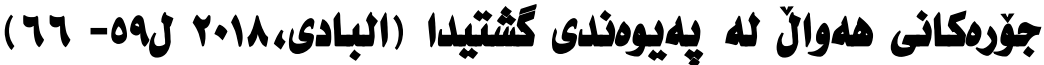

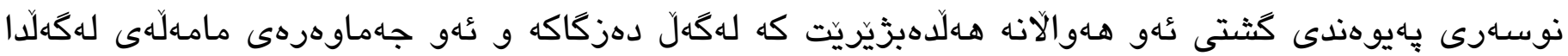

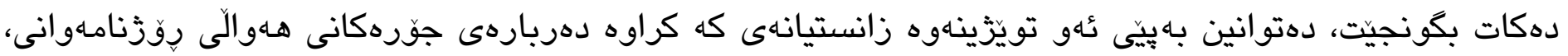

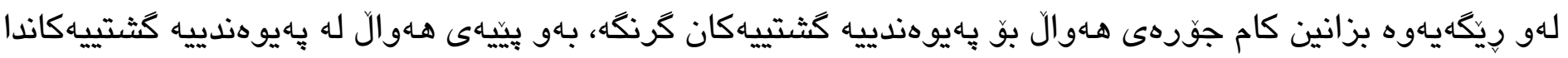

$$
\text { دابهشدهبيت بوّ ثُهم جورانهى خوارهوه: }
$$

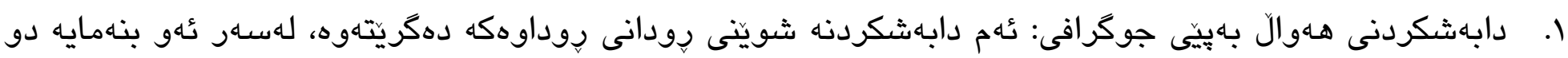

$$
\text { جوّر هـاوال هـهيه: }
$$

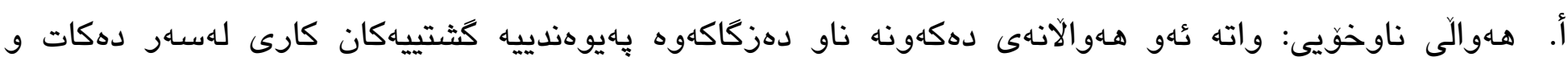

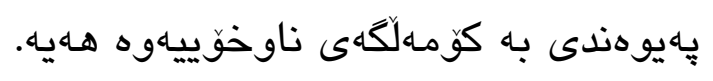

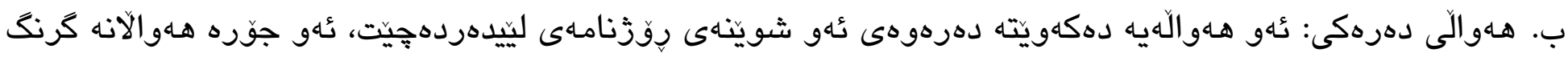

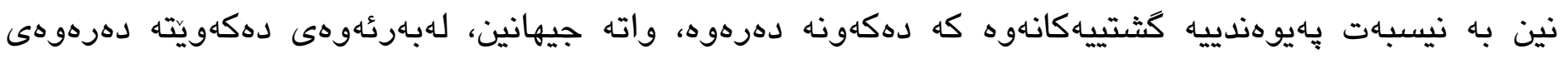

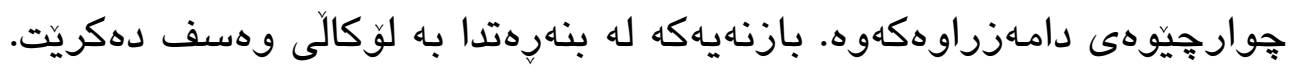

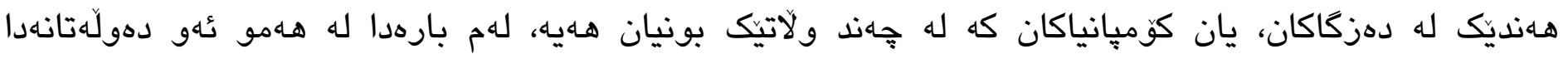

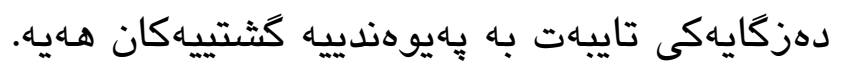

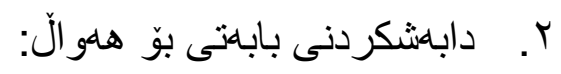

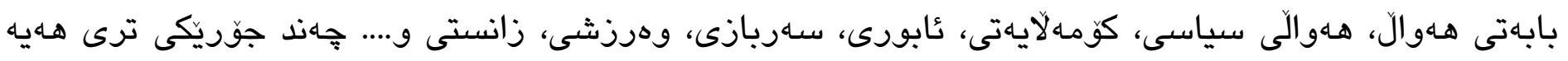

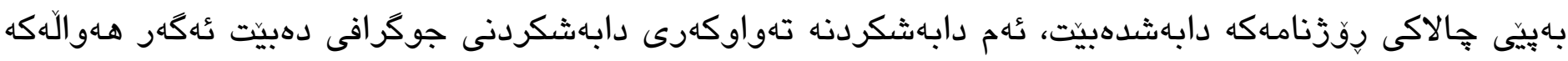
ناوخوّيى بن، يان دهرهكى.

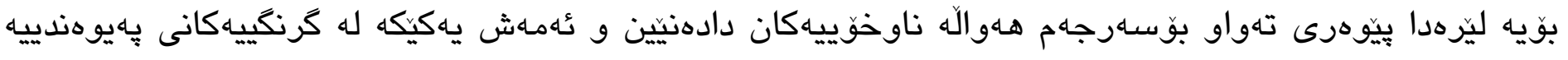

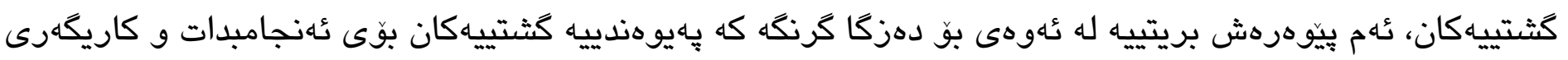

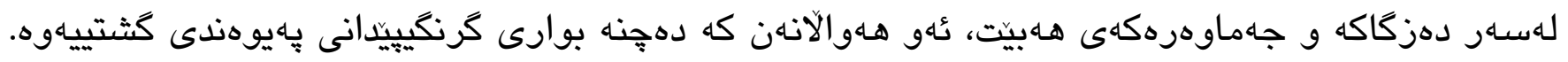

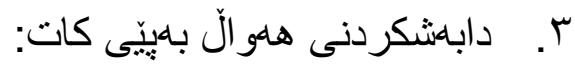

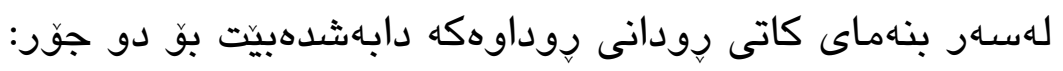

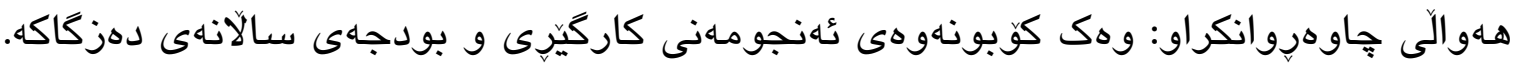

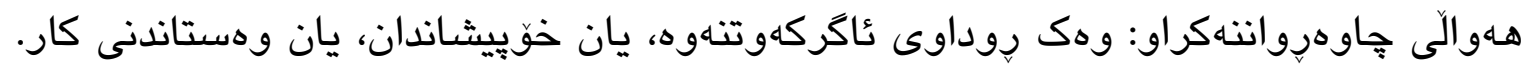

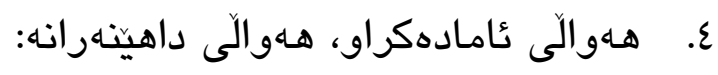

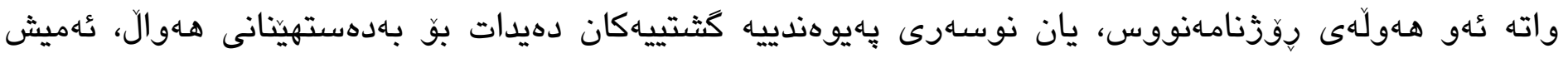
دابهشدهبيت بوّ دو جوّر: 


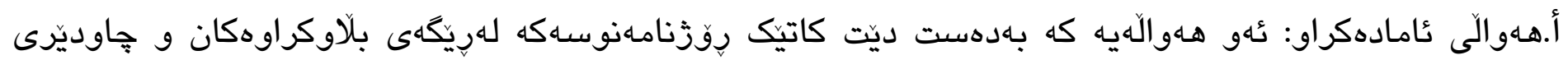

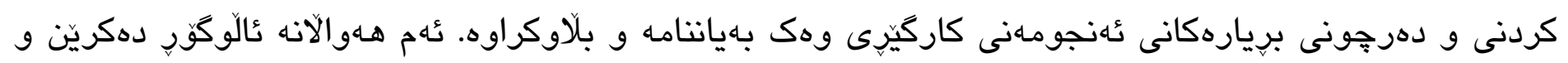

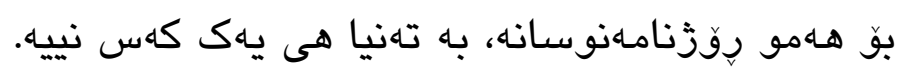

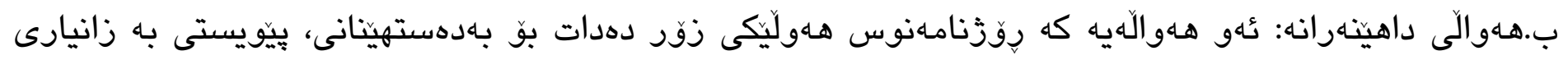

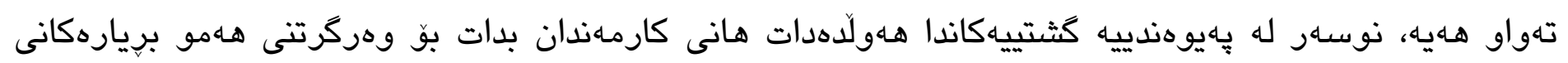
دهزكاكه تا كُهيشتن بـاه تُهنجام.

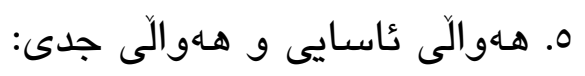

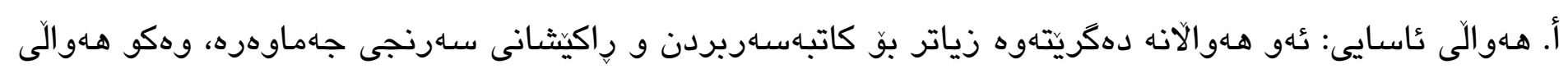
وهرزشى و هونهرى و ئهستيرهكان و ئهدهب.

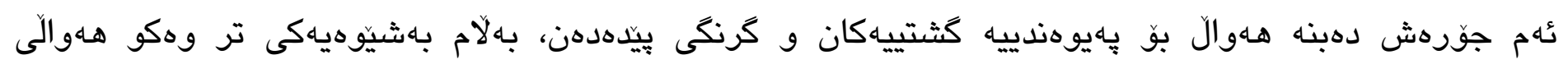

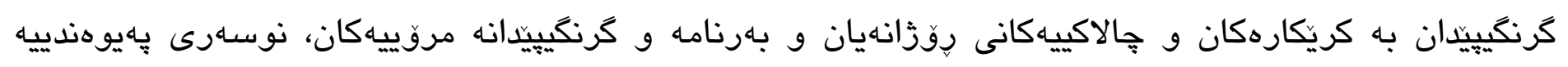

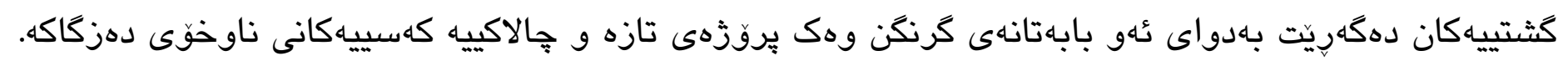

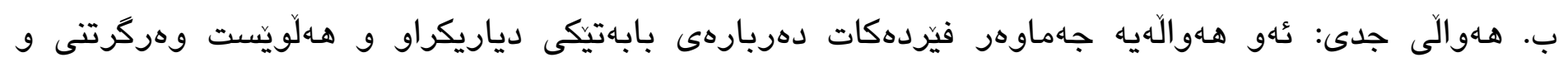

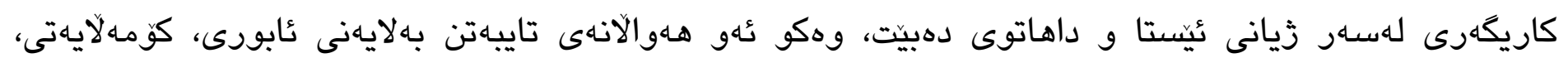
فيَركردن و تهندروستى و........

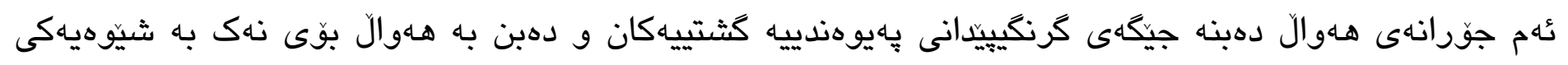
فراوان زياتر له ناوخَى دهزكاكهدا دهمينيتهوه. تويّزينهوه زانستيهكان له بوارى يهيوهندييه كثتييهكاندا زياتر جهخت لهوه دهكهنوه كه روداوهكانى وهكو

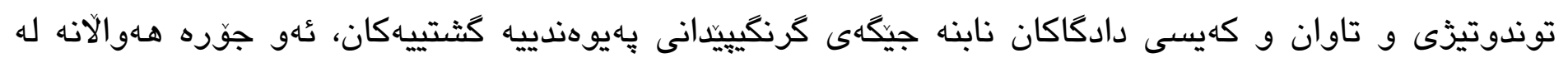

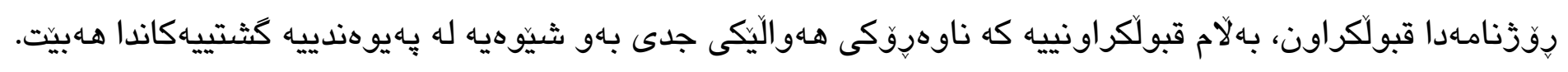
7. هـهوالى بابهتى و هـهوالى شيكهردوه:

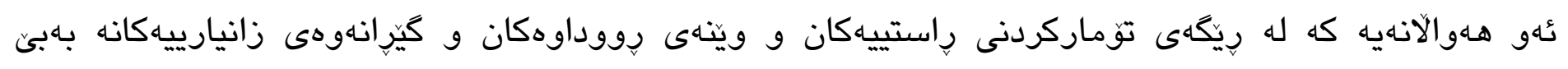

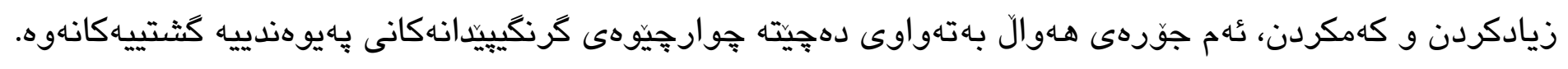

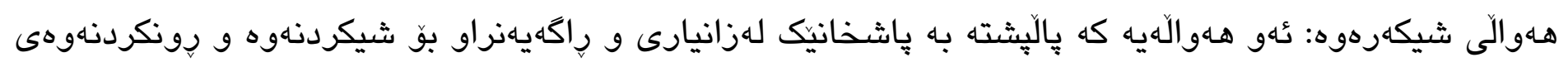

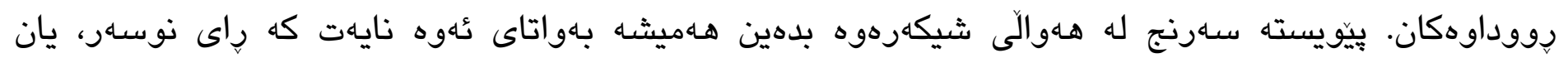

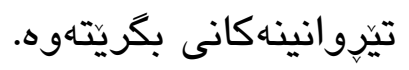




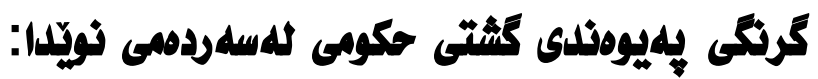

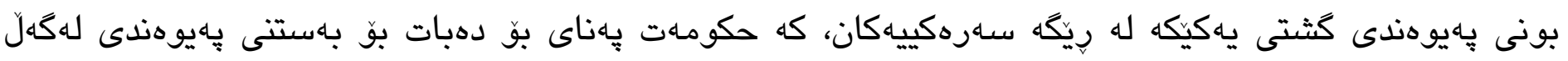

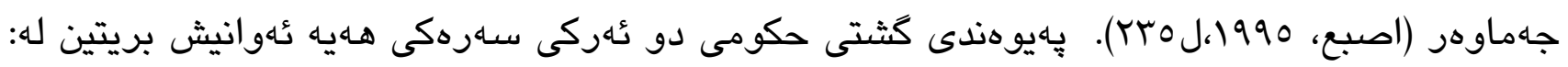

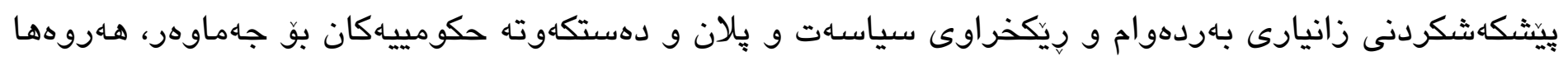

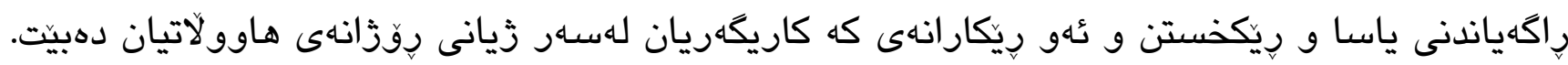

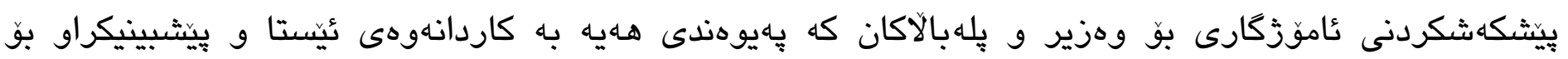

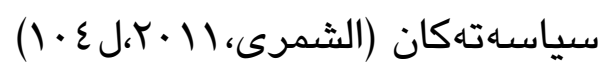

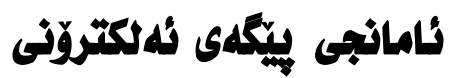

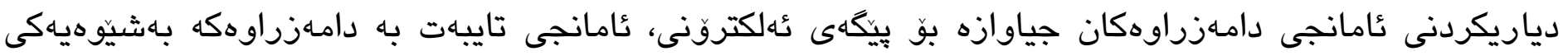

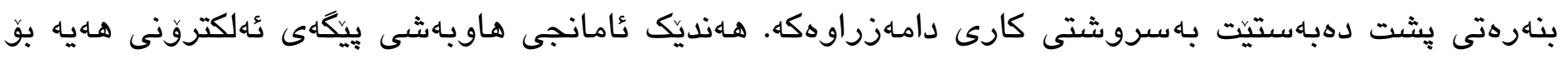

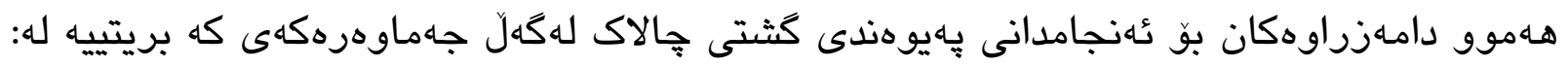

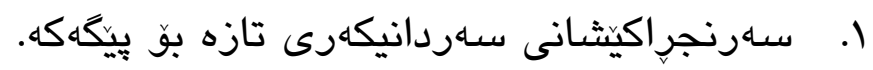

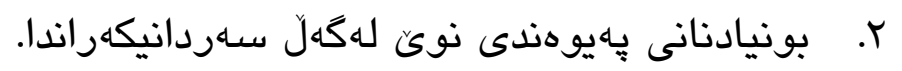

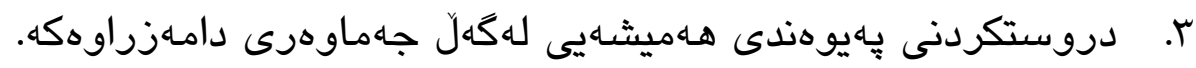

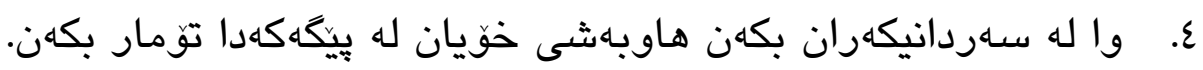

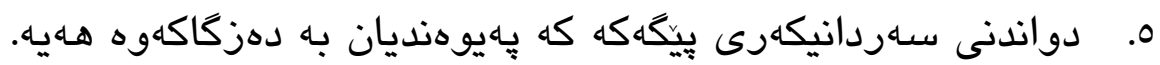

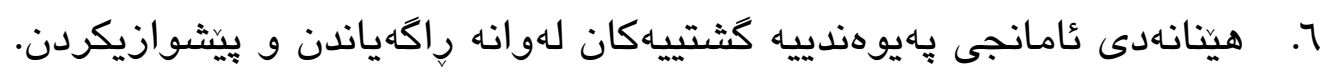

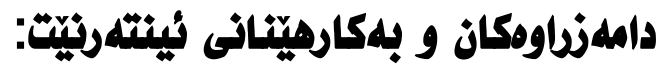

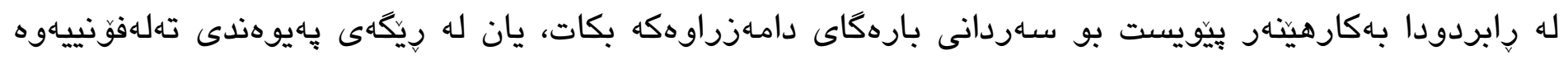

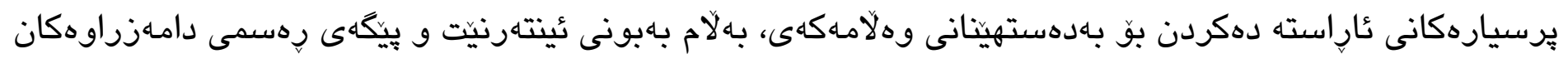

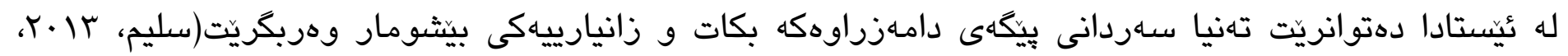




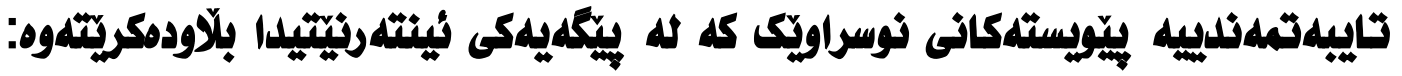

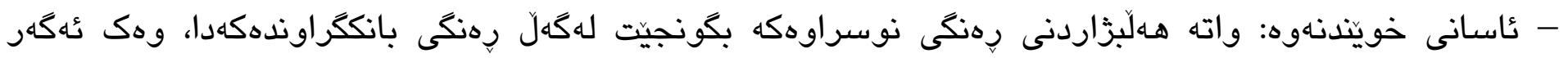

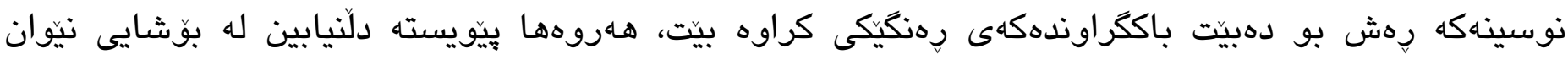

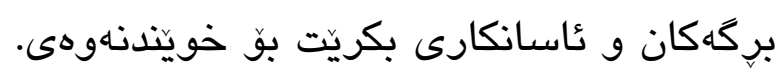

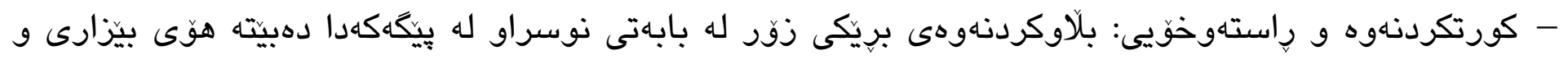

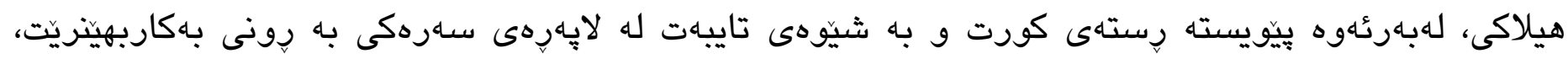

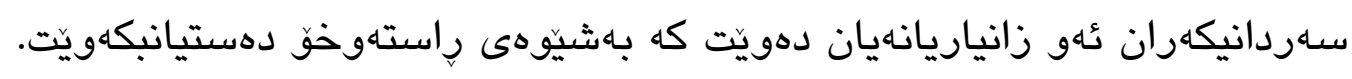

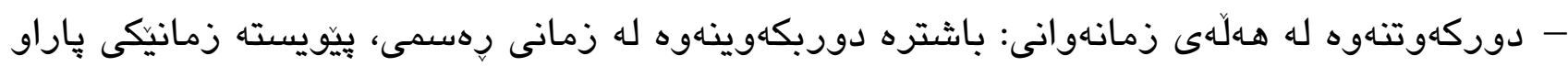

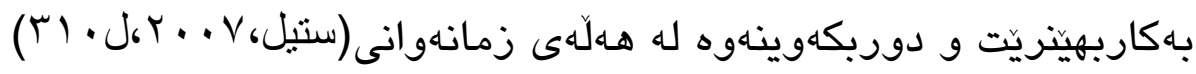

\section{بايهنى هراكتيكى:}

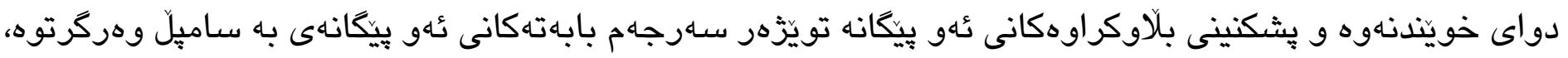

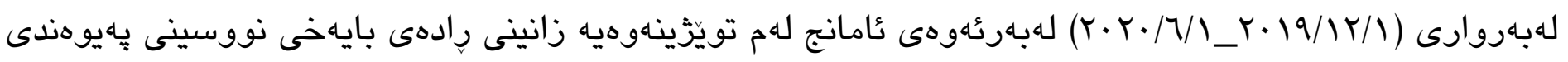

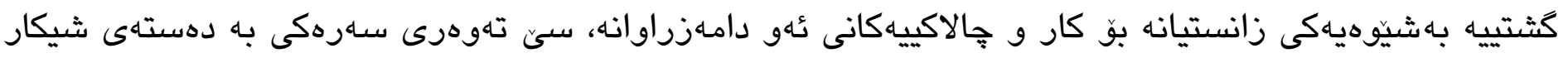

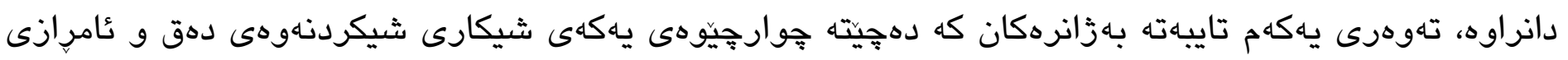

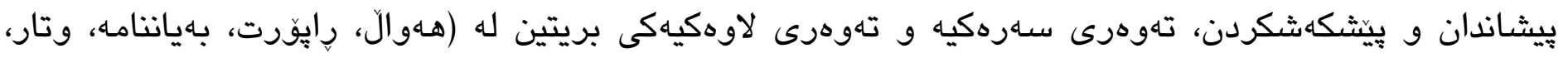

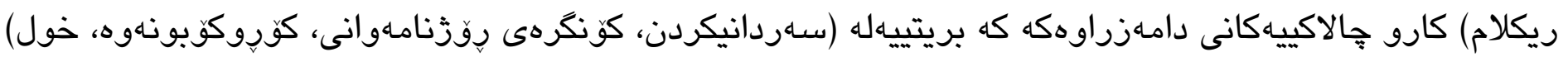

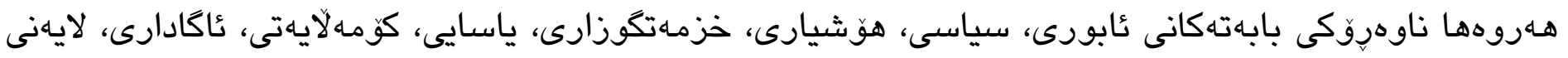

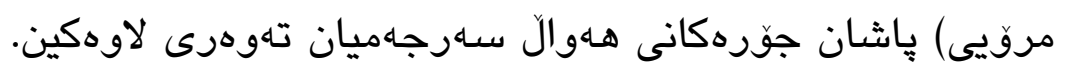

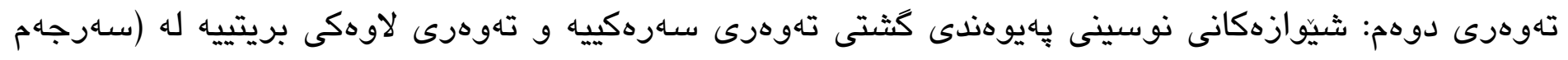

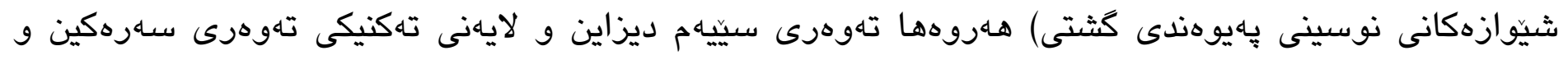

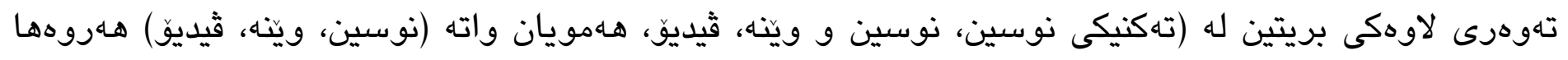

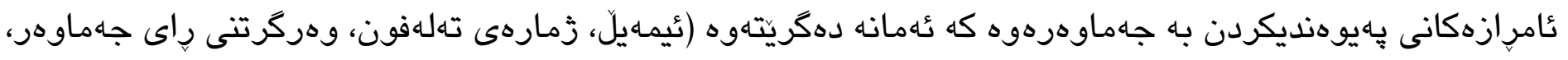

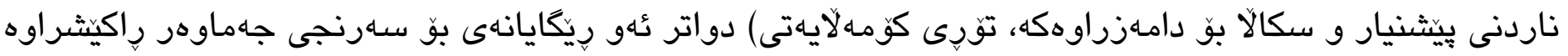

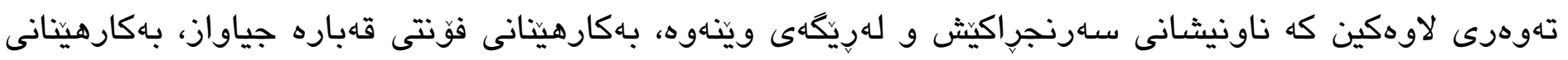

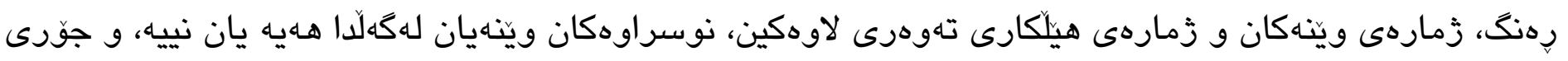
ويتنهان تهوهرى لاوهكين. 


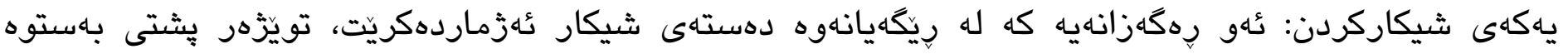

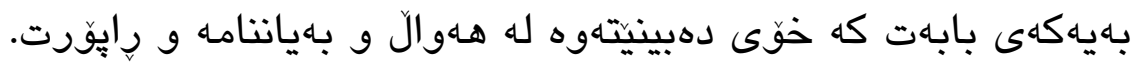

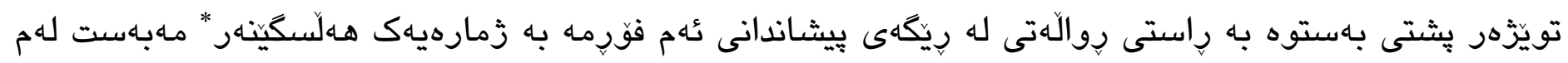

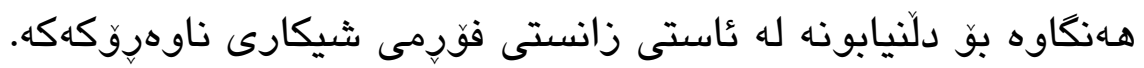

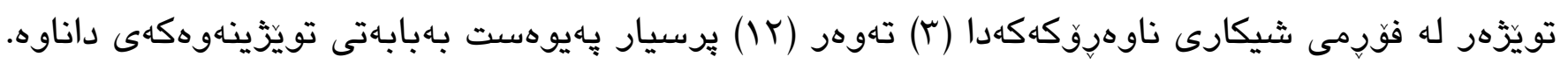

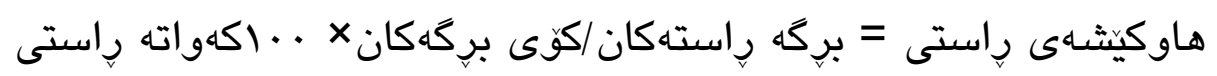

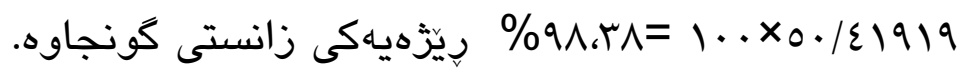

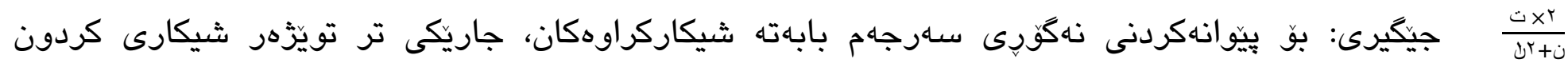

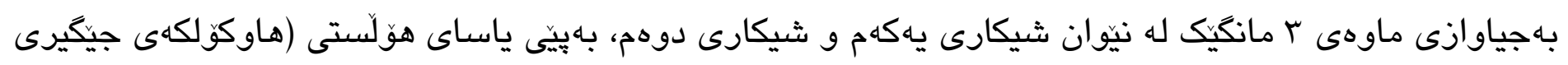

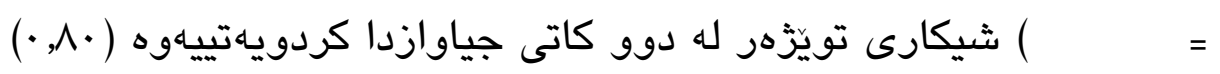

\begin{tabular}{|c|c|c|c|c|c|c|}
\hline 4t & كوّ & 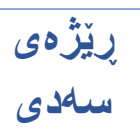 & رايوّرث & 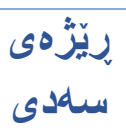 & هلوالّ & دامهزراوه \\
\hline سبّيهم & 11 & \%rr & 1 & $\% r \varepsilon$ & 1. & 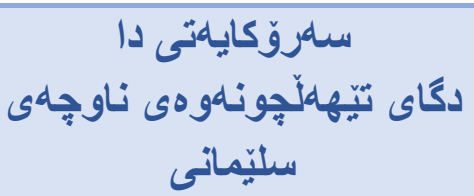 \\
\hline دوهم & 10 & سب\% & 1 & $\%$ & $1 \varepsilon$ & 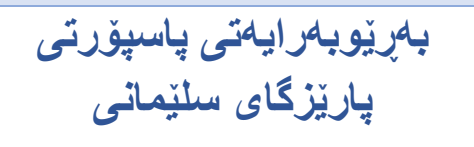 \\
\hline ياككهم & 11 & س & 1 & $\% \leqslant 1$ & IV & 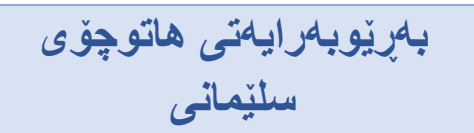 \\
\hline
\end{tabular}

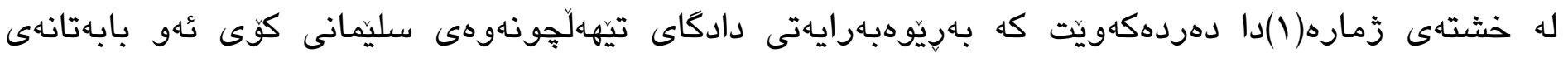

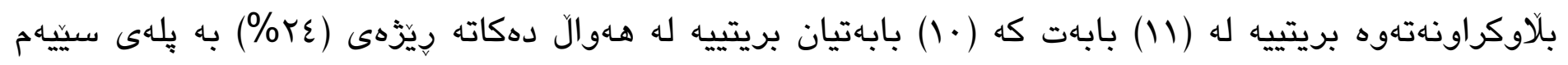

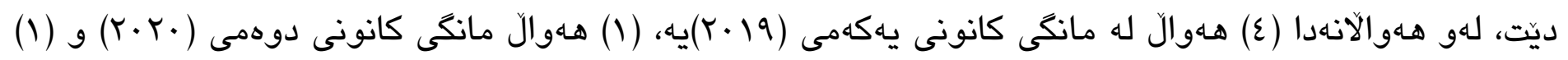

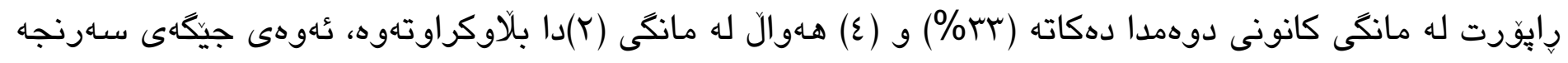

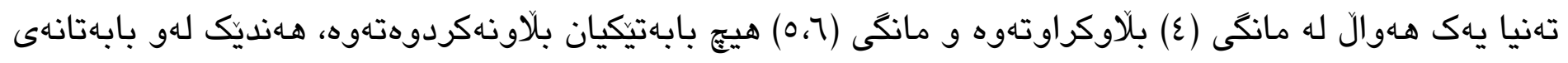

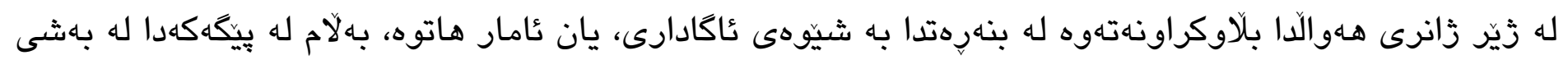

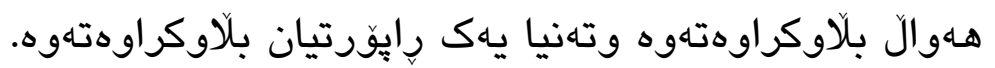




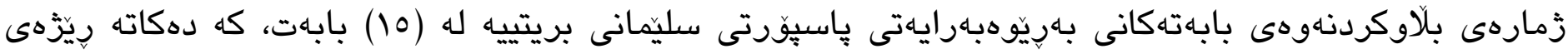

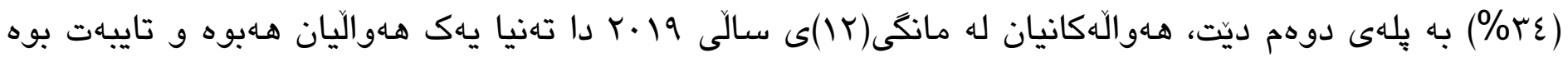

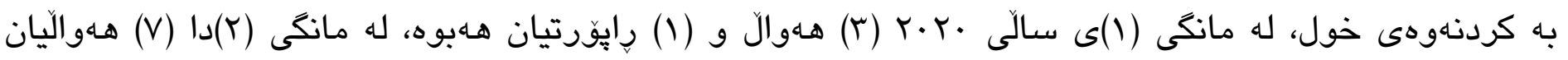
هـهوه، واته زورترين جُالاكيان له مانكى دودا ئهنجامداوه، له مانكى (r) تهنيا يهك هـوالَ بلاّوكراوهتهوه، ئهويش

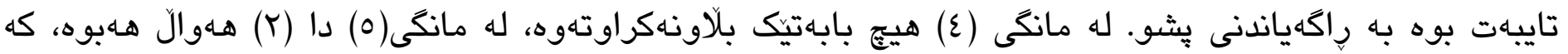
كأهوانيش عاكادارى بون.

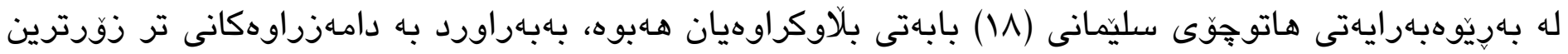

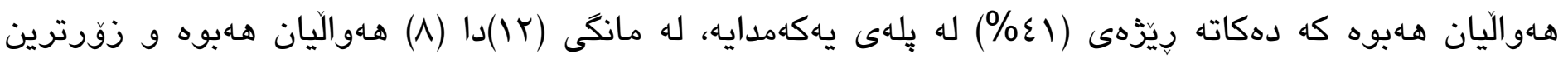

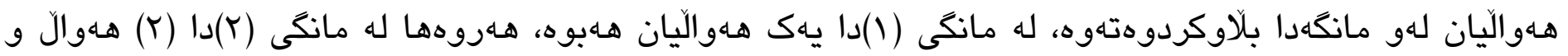

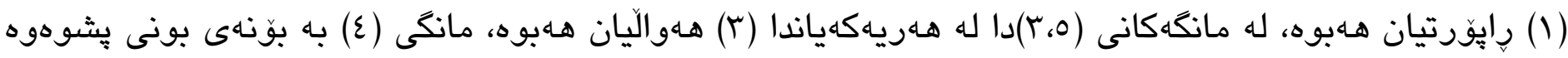
هيج هـواليّكيان نهبوه.

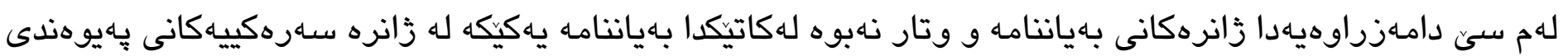

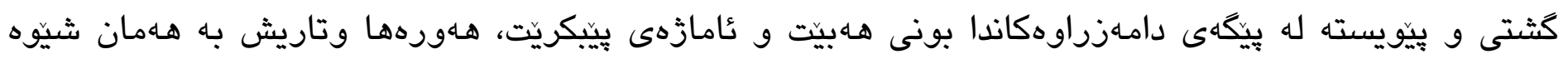
بونى نييه له هيج يهكيك لهو بينيًانه.

خشتهى زماره (Y) ئهو جالاكيانهى دامهرزاوهكان ئهنجاميان داوه

\begin{tabular}{|c|c|c|c|c|c|c|c|}
\hline بله & ريّزْهى & كوّ & خول & كوّروكوّيونهوه & سيمينار & سلهرد|تيكردن & دامهزراوه \\
\hline يمكام & $\%{ }^{\circ}$. & 9 & 1 & $r$ & Y & $\varepsilon$ & 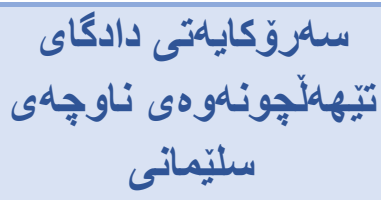 \\
\hline 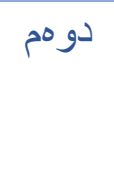 & \%rr & 7 & r & . & 1 & $r$ & 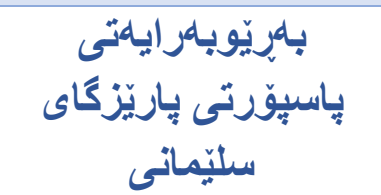 \\
\hline سيّياهم & $\%) \mathrm{V}$ & $r$ & . & . & 1 & r & 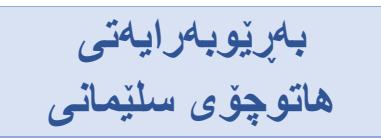 \\
\hline & $\% 1 \ldots$ & 11 & $r$ & r & $\varepsilon$ & 9 & كوّى كثتى \\
\hline
\end{tabular}

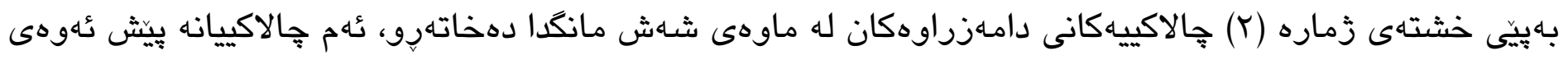

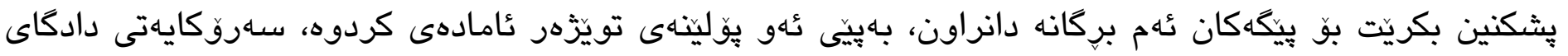




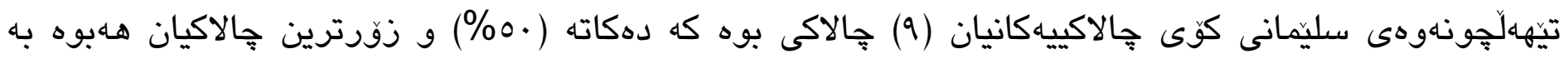

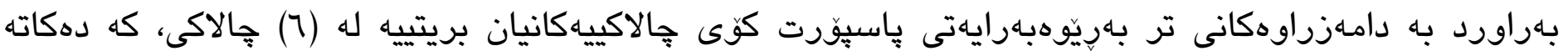

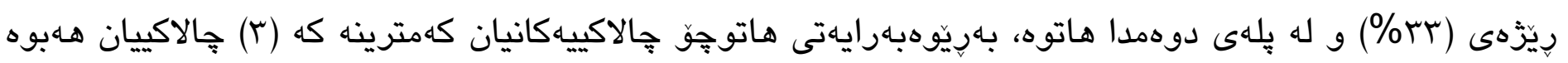

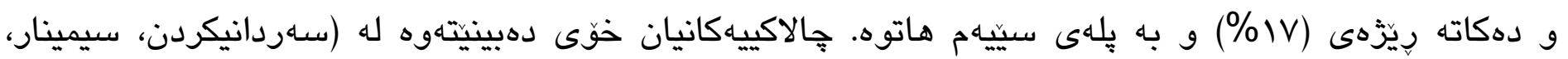

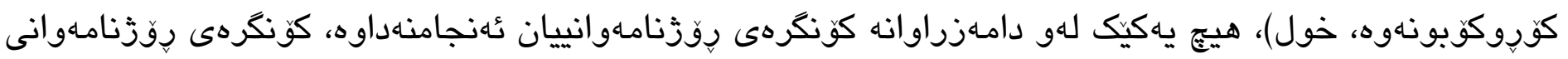

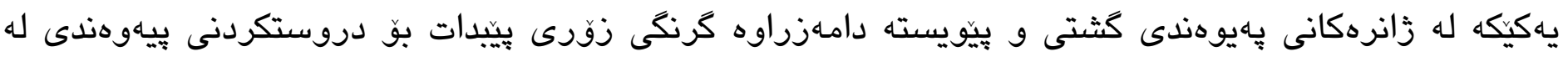

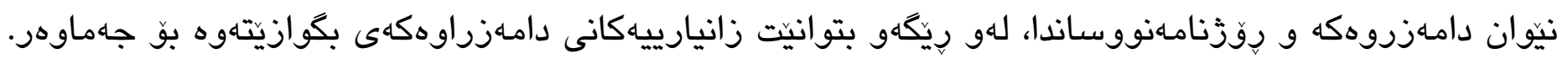

\section{خشتهى زماره (ז) ناوهرِكى بابهتهكان}

\begin{tabular}{|c|c|c|c|c|c|c|}
\hline يله & سيزّنهى سلدى & كوّ & 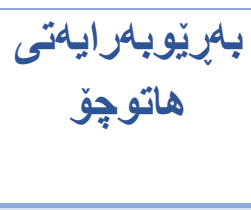 & بهِيَّبهربايهتى & 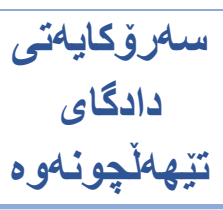 & بابهتهكان \\
\hline بِيّنجاهم & $\% r_{6} r V$ & 1 & . & 1 & 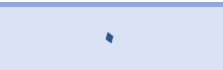 & سباسى \\
\hline سبِيهم & \% & 7 & 1 & r & r & هوَشيارى \\
\hline دو مم & $\%$ Yo & 11 & r & $r$ & 7 & خزمهنكوزارى \\
\hline يِّنجام & $\% 7_{6} \wedge 1$ & r & 1 & . & r & ياسايى \\
\hline جو ارهم & $\% 96.9$ & $\varepsilon$ & r & r & . & كوّمـهلاِيانتى \\
\hline ياككهم & $\%=.69$. & 11 & 11 & 7 & 1 & ئاكَادارى \\
\hline \multirow[t]{2}{*}{ يَّنجام } & $\% Y_{6} Y_{V}$ & 1 & 1 & - & . & لايهنى مرويّى \\
\hline & $\% 1 \ldots$ & $\varepsilon \varepsilon$ & 11 & 10 & 11 & كوَى كُثتى \\
\hline
\end{tabular}

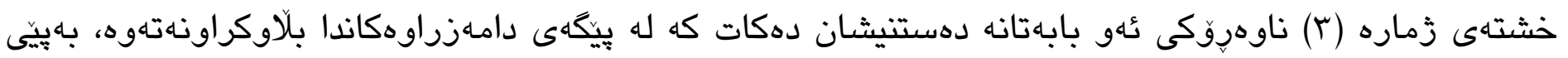

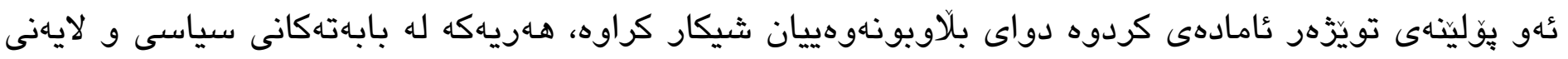

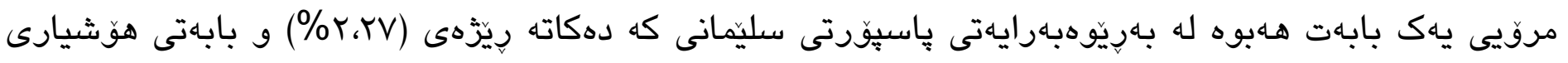

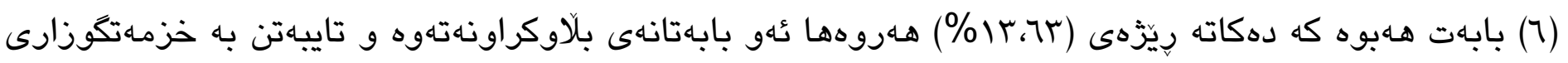

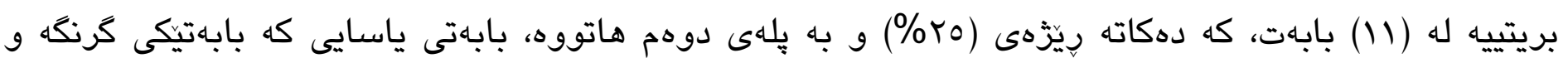

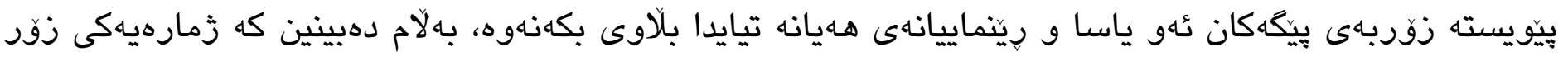

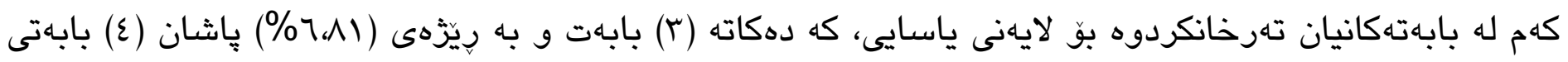

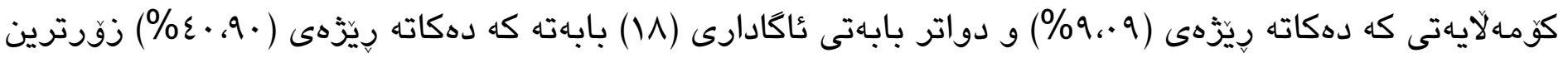

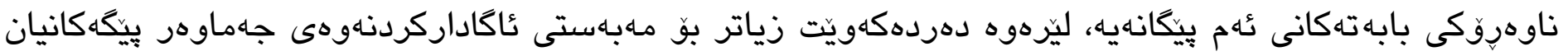




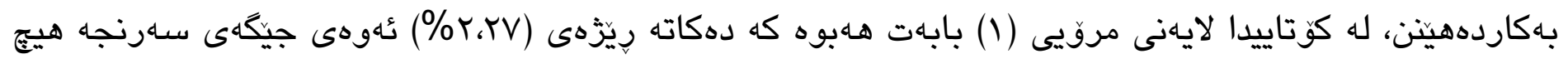
بابهتيكى ئابورى باس نهكراوه، لهكاتيكدا بابهتى نابورى يهكيكه له بابهته سـهرهكييهكانى هـمو دامـزراوهيهك و

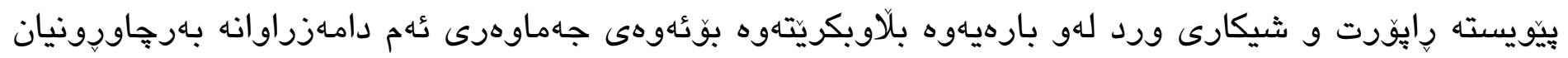
لهو بوارهدا هـاهبيت.

\begin{tabular}{|c|c|c|c|c|c|c|}
\hline يله & ريّزْهى & كوّ & بالِيَوبـهر ايانتى & 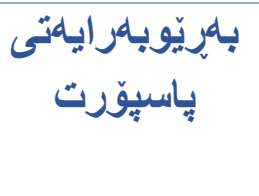 & 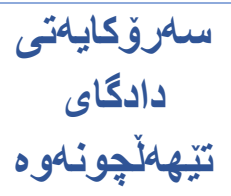 & جوّرهكانى هلوالّ \\
\hline سيّيهم & $\%$ YVG $r V$ & rq & 17 & 11 & 9 & دامهزوراولى نـاوخوّيى \\
\hline جو ارهم & $\% 76.7$ & $\wedge$ & r & $\varepsilon$ & r & 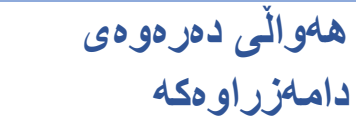 \\
\hline دوهم & $\%$ Y9.0 & rq & 10 & IT & 11 & هلوالَى جاوهروانكراو \\
\hline يَّنججام & \% r、VA & 0 & $r$ & r & - & هاو هِرو الْى انتهكر او \\
\hline ياككهم & 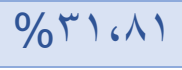 & $\varepsilon r$ & 11 & $1 T$ & 11 & هلوالّى بابهتى \\
\hline \multirow[t]{2}{*}{ شاششاهم } & $\% 1.01$ & r & ' & r & • & هلوالْى شيكلرهوه \\
\hline & $\% 1 \ldots$ & Ir & $0 \leqslant$ & $\varepsilon 0$ & r & كوّى كشّتى \\
\hline
\end{tabular}

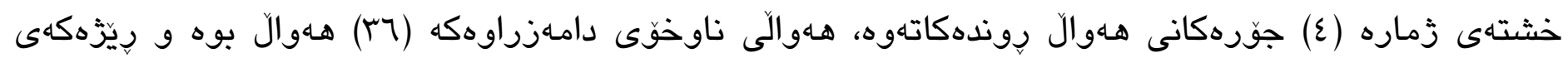

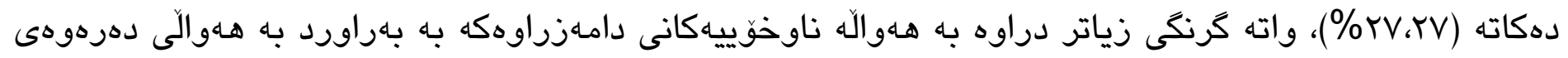

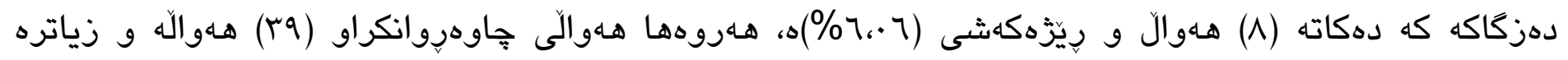

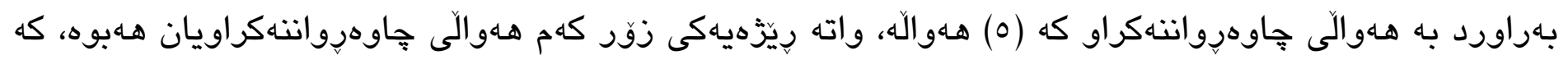

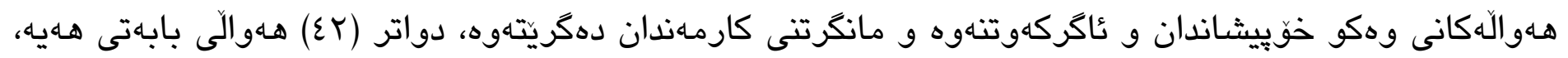

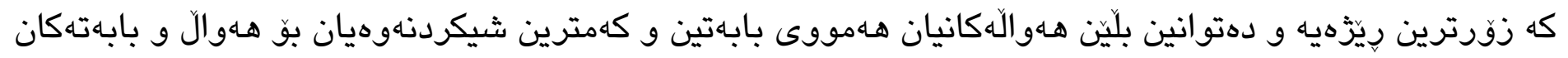

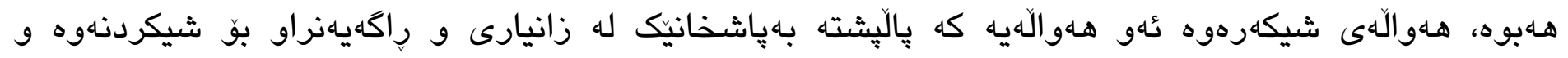

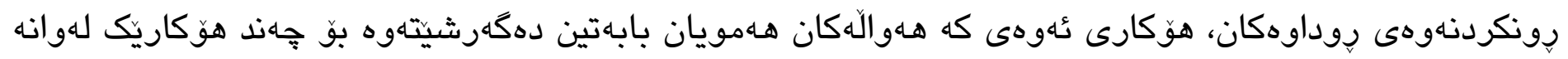

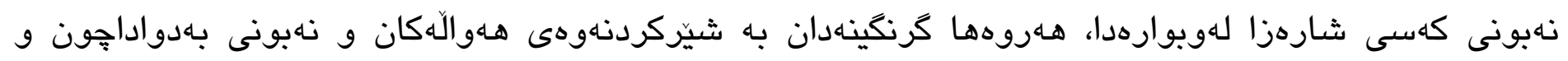

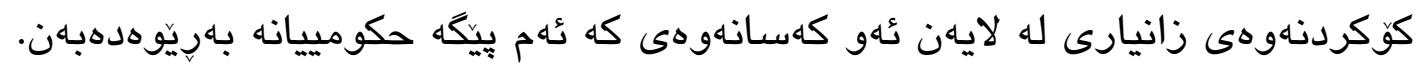




\begin{tabular}{|c|c|c|c|c|c|c|}
\hline "يله & 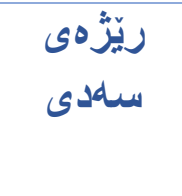 & كوّ & هاتِويَوبهر ايهنتى & بهِيَّيَهِرايهتى & 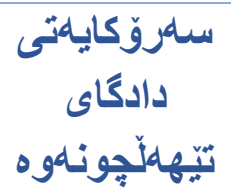 & 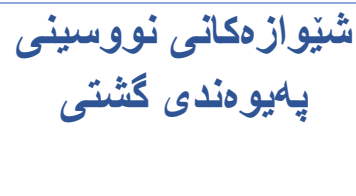 \\
\hline سيّيهم & $\% 96.9$ & $\varepsilon$ & 1 & r & 1 & شُيَوازى باو \\
\hline يَّنجاهم & - & - & - & - & - & شُيَوازى بِيشُهيى \\
\hline دوهم & $\%$ \% 6 TV & Ir & V & r & r & 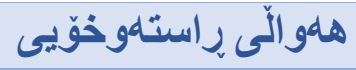 \\
\hline جو ارهم & $\% 7, \wedge 1$ & $r$ & 1 & 1 & 1 & بهدواداجونى نئاسـايق \\
\hline 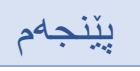 & - & - & • & - & - & شيَيوازى باسايى \\
\hline يَّنجانم & $\cdot$ & $\cdot$ & - & $\cdot$ & - & شُيِوازى كهسى \\
\hline \multirow[t]{2}{*}{ يلمكهم } & $\% \circ 7_{6} \wedge 1$ & ro & 9 & 1. & 7 & شَيْوازى كار \\
\hline & $\% 1 \cdot$ & $\varepsilon \varepsilon$ & 11 & 10 & 11 & كوّى كشثتى \\
\hline
\end{tabular}

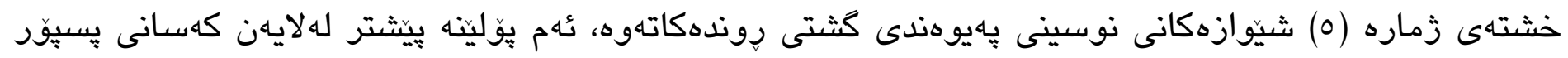

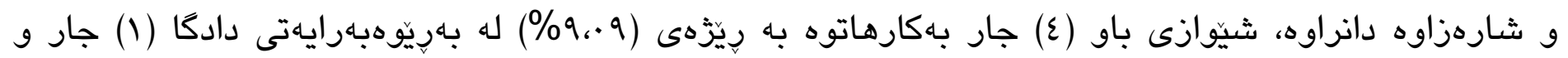

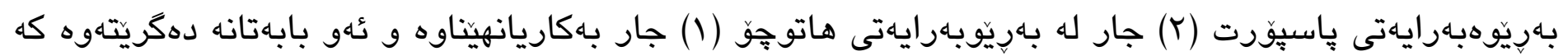

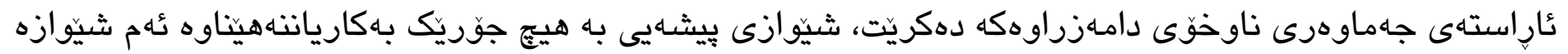

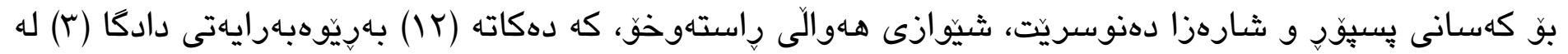

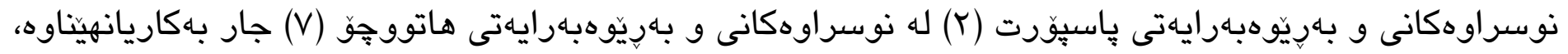

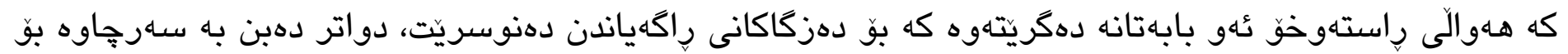

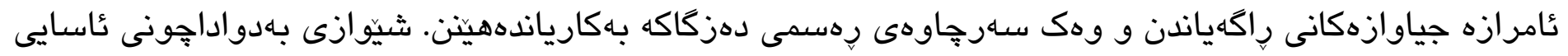

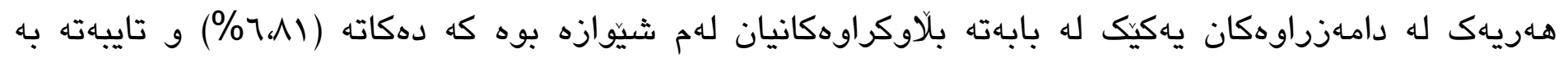

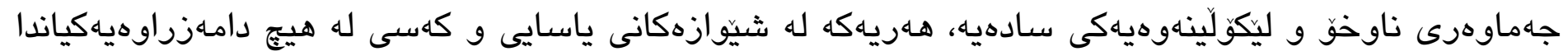

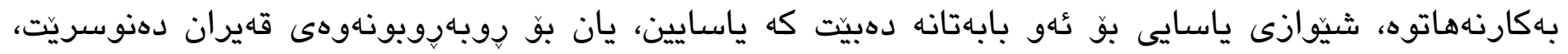

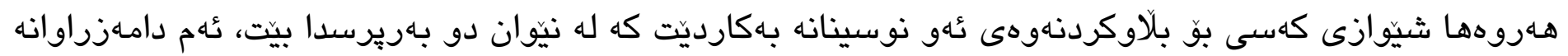

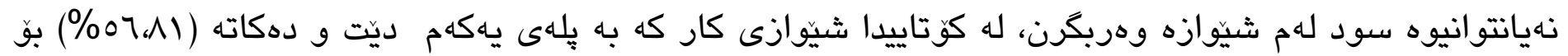

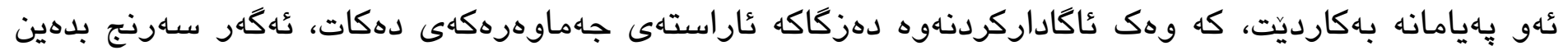

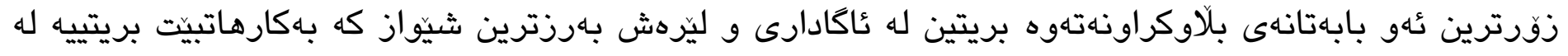

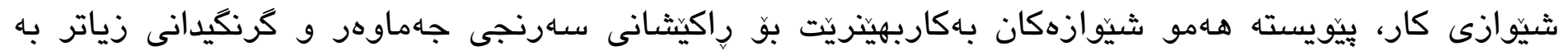

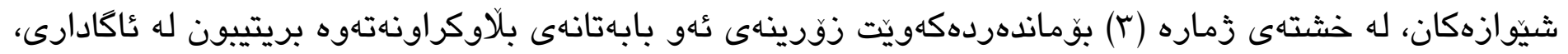




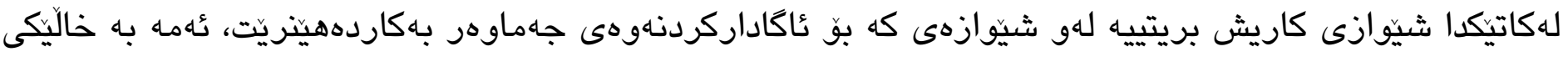

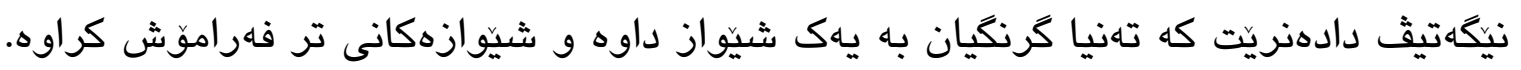

خشتهى زماره (1) تاييهته بهلايهنى تهكنيكى

\begin{tabular}{|c|c|c|c|c|c|c|}
\hline بـله & 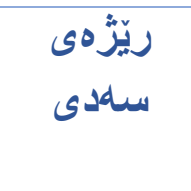 & كوّ & 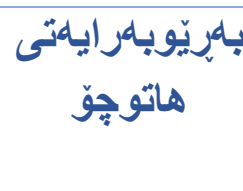 & 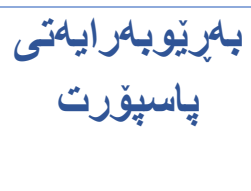 & 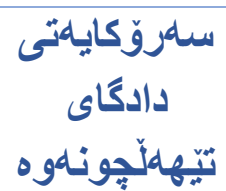 & تهكنيكى \\
\hline دوهم & $\% \varepsilon \cdot 69$. & 11 & 11 & 0 & r & نوسين \\
\hline ياككهم & $\% \circ 7_{6} \wedge 1$ & ro & V & 9 & 9 & نوسين و ويَنه \\
\hline سيّاه & $\%$ YGV & 1 & . & 1 & . & قيديو \\
\hline & $\% 1 \ldots$ & $\varepsilon \varepsilon$ & 11 & 10 & 11 & كوّى كَثتّى \\
\hline
\end{tabular}

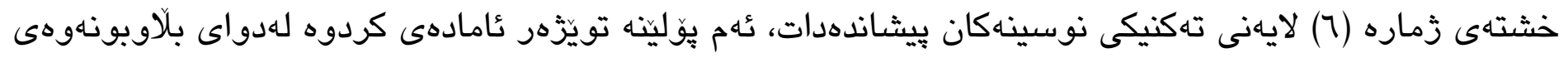

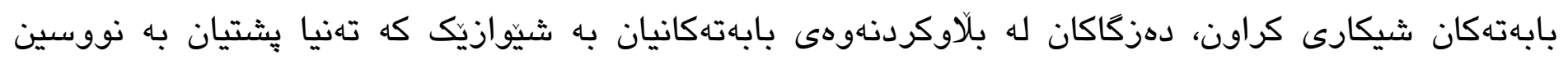

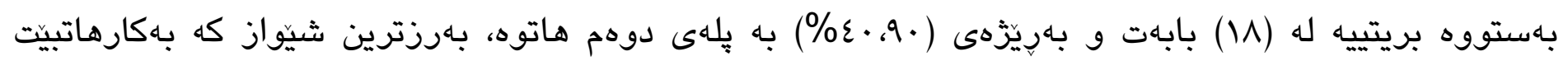

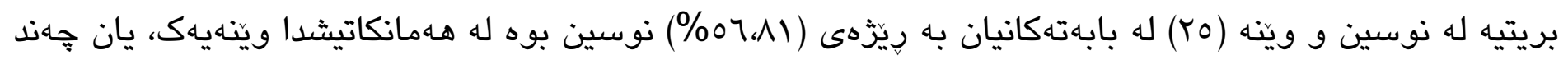

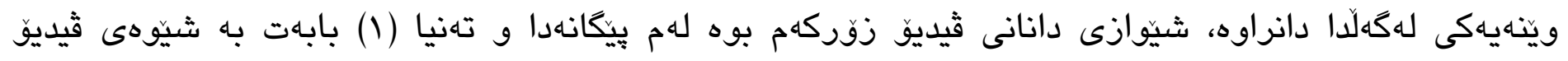

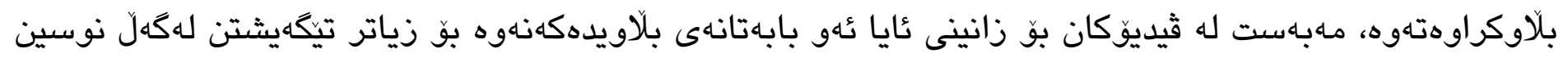

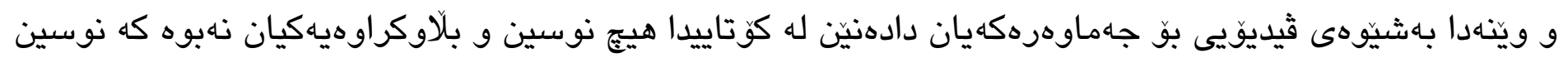
و وينّه و ثيديوى تيّا بيت.

خشتهى زماره (V) ئامرازهكانى بهيوهندى دامهزراوهكه به جهماوهرهوه

\begin{tabular}{|c|c|c|c|c|}
\hline كوّ & هباتيّوبهر ايهتى & 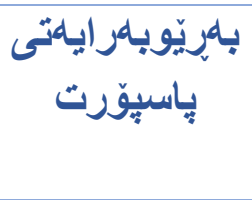 & 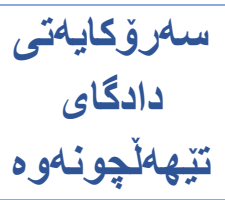 & ئامرازهكانى بـايوهندى \\
\hline r & بافلّى & بالّْى & بهلّيّ & نيماعلّ \\
\hline r & بـلّى & باعلّى & بافلّى & زمارهى تـلذلفون \\
\hline r & باكلّى & باعلّى & 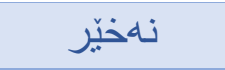 & وهركرتنى يراى جامماوهر \\
\hline r & باعلّى & بالّْى & نَهْيّر & ناردنى بِيشنيار و سكالّا بوّ داملزراوهكه \\
\hline r & باعلّى & بافلّى & بالّى & توّرى كوّمهلاًاياتى \\
\hline M & 0 & 0 & $r$ & كوَى كَشتى \\
\hline
\end{tabular}


خشتهى زماره (V) ئهو ئامرازانهى پٍهيوهندى نيّوان دامهزراوهكه و جهماوهر بهيهكهوه دهبهستيتهوه دهخاتهرو له

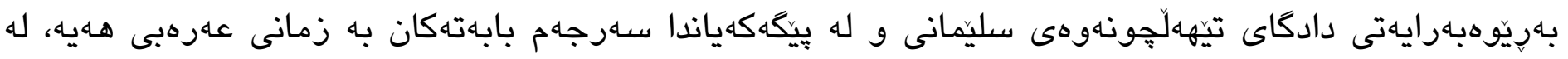

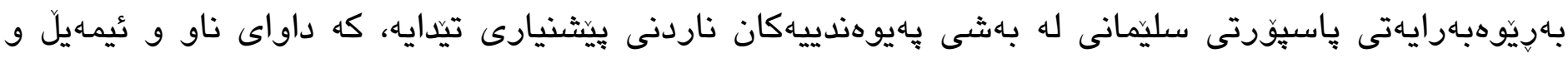

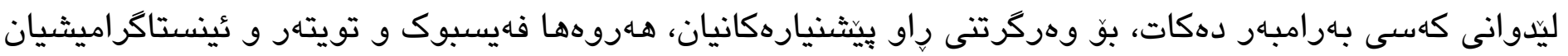

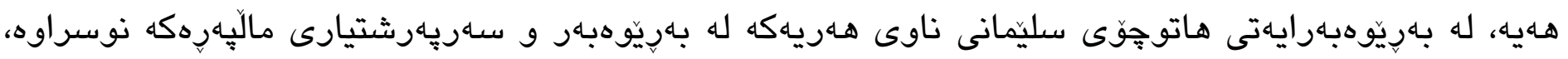

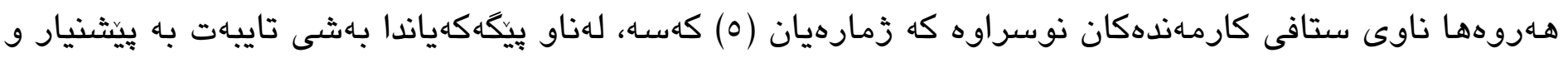

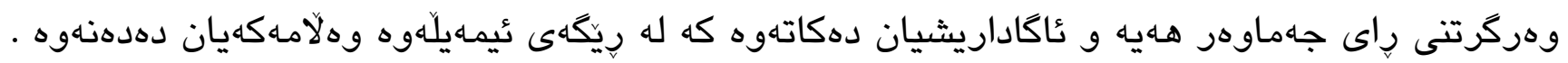

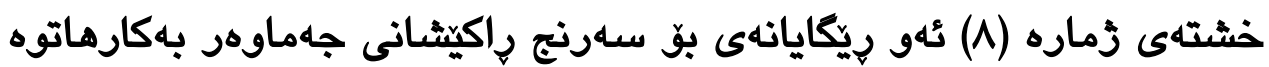

\begin{tabular}{|c|c|c|c|c|}
\hline كوّى كشتى & 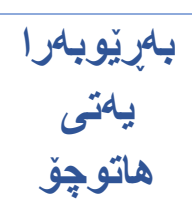 & 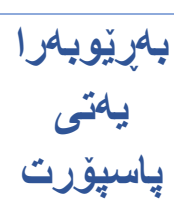 & 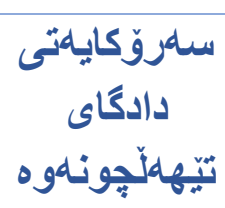 & ريّكاكانى سهرنج رِاكيَثانى جهماوهر \\
\hline . & $x$ & $x$ & $x$ & ناونيشانى سلهرنجِ اكيّش \\
\hline r & $x$ & $\sqrt{ }$ & $\sqrt{ }$ & له ريّيحهى وينتهوه \\
\hline • & $x$ & $x$ & $x$ & باكار هينانى فوّنتى قهباره جياواز \\
\hline • & $x$ & $x$ & $x$ & باككار هينانى ررنـى \\
\hline
\end{tabular}

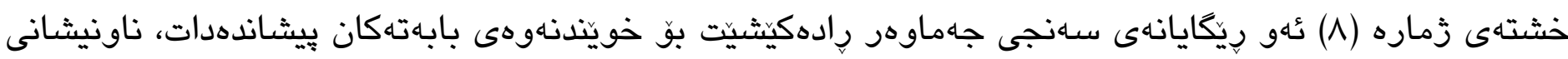

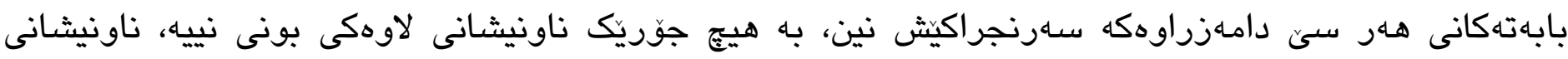

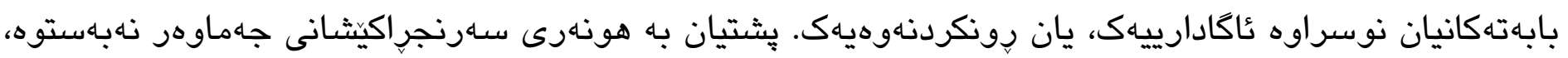

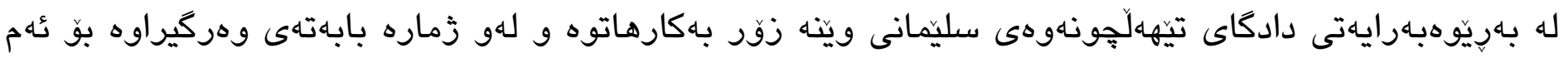

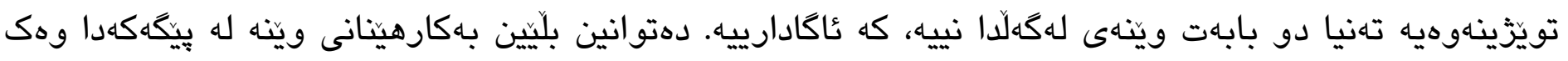

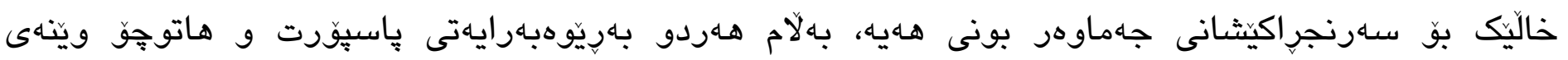

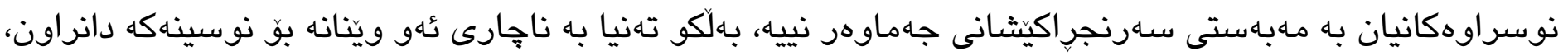

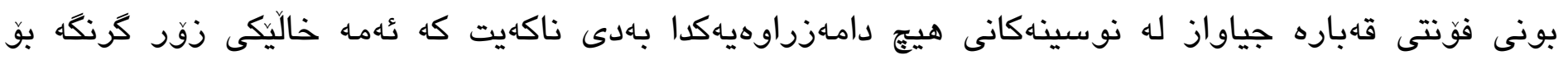

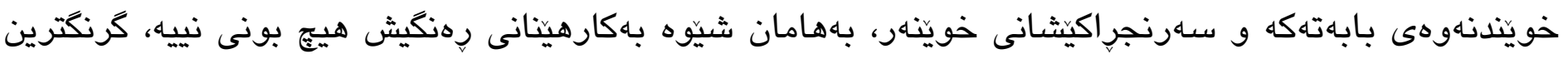

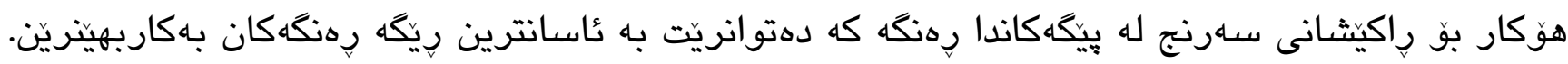


خشتهى زُماره (9) بهكارهينانى وينه و هيلكارى

\begin{tabular}{|c|c|c|c|c|c|c|}
\hline ريّزْهى سهدى & هاتو جِو & سرهدئهى & باسِيوزرت & سردّلىى & دادكا & ويَنْه و هينّكارى \\
\hline$\%$ \% & $\leq V$ & \% Yr.IV & ro & $\% \leqslant 0.79$ & 79 & زَمارهى وينتهكان \\
\hline$\% 1 \ldots$ & \multicolumn{4}{|c|}{101} & & كوّى كَثتى \\
\hline
\end{tabular}

خشتهى زماره (9) زمارى ئهو ئهو وينانهى بو بابهتهكانى ئهم تويَّزينهوهيه وهركيراون دهردهخات، كوَى كَثتى

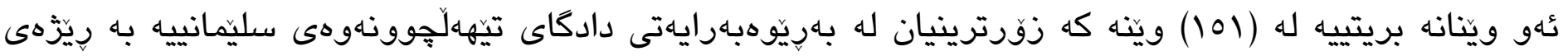

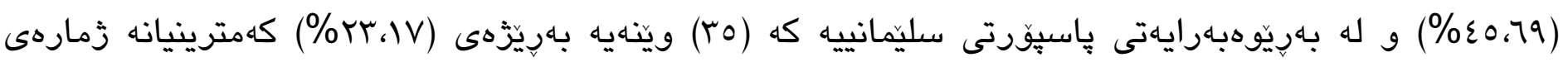

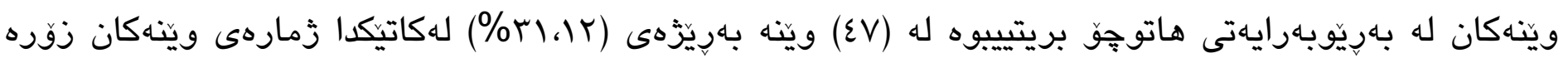

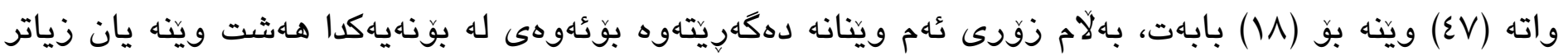

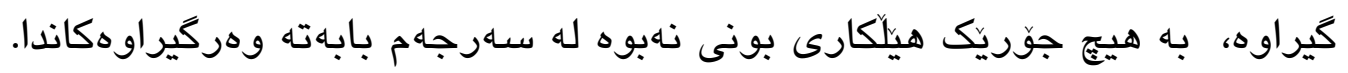

خشتهى زماره (•(1) نوسراوهكان ويتَهيان لهكهلدايه، ياخود نا

\begin{tabular}{|c|c|c|c|c|c|c|}
\hline يله & ريّرَثى سلهى & زثماره & 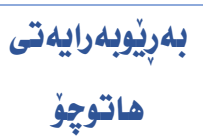 & 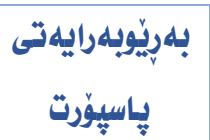 & 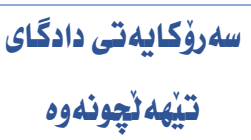 & ويّنه \\
\hline يلكهم & $\% 07,11$ & ro & V & 9 & 9 & ويَنهيـان لهَّه لَدايه \\
\hline دوهم & $\% \leqslant \mu, 11$ & 19 & 11 & 7 & r & ويّنهيـان للهَّهل لَدا نييه \\
\hline & $\% 1 \ldots$ & $\varepsilon \varepsilon$ & 11 & 10 & 11 & كَوى كَشتى \\
\hline
\end{tabular}

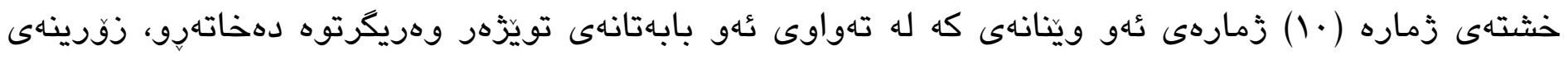

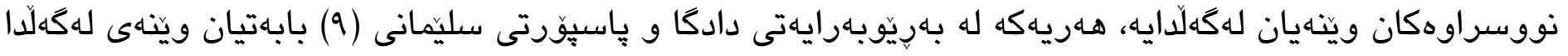

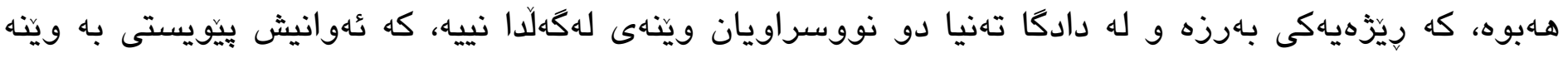

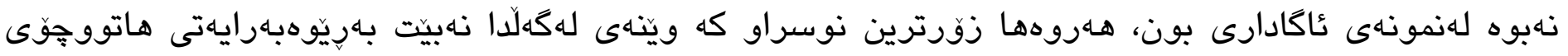

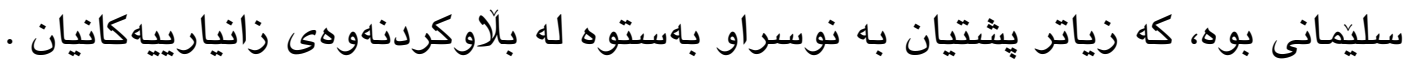


خشتهى زُماره (11) جوردى وينّكان

\begin{tabular}{|c|c|c|c|c|c|c|}
\hline ليله & ريّزْهى سدلى & كوّ & 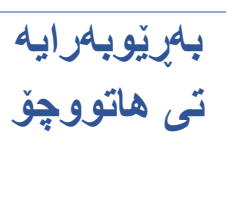 & 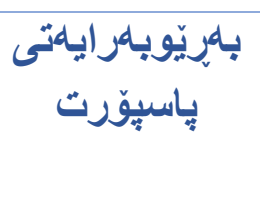 & 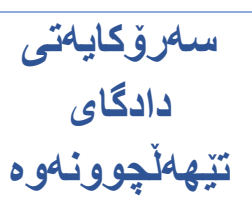 & جوَرى ويّنه \\
\hline ياككهم & $\% \circ r$ & IT & 7 & 7 & 1 & كلسايلتى \\
\hline جو ارمم & $\cdot$ & · & . & · & • & روداو \\
\hline دومم & $\%$ \%r & $\wedge$ & · & · & $\Lambda$ & كوّبونـهوه \\
\hline \multirow[t]{2}{*}{ سيّيهام } & $\% 17$ & $\varepsilon$ & 1 & $r$ & · & هيتر \\
\hline & $\% 1 \ldots$ & ro & v & 9 & 9 & كوّى كشتى \\
\hline
\end{tabular}

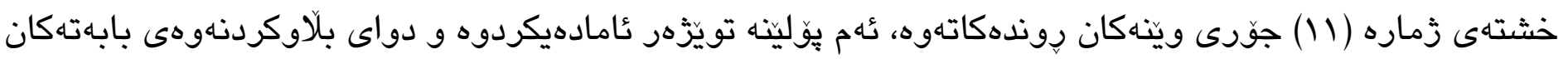
شيكارى كردوه، ويناهى كهايهتييهكان يهكيك بوه لهو ويناناهى كه له زوريناهى بابهتهكاندا بهدى كراوه و بهرزترين

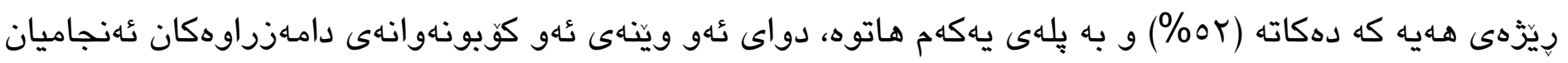

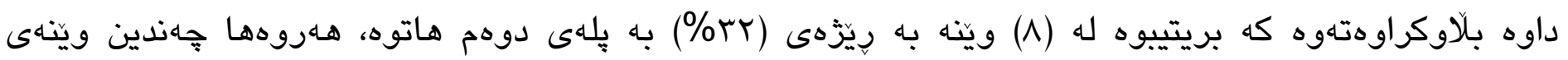

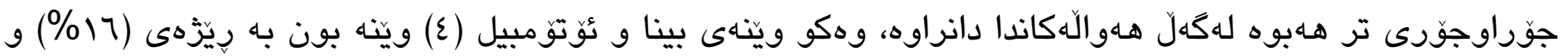
له يلهى سينيهمدا هاتوه.

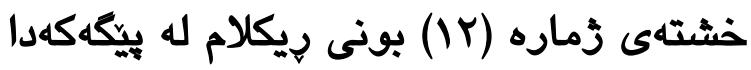

\begin{tabular}{|c|c|c|c|c|c|}
\hline سيَّنهى & 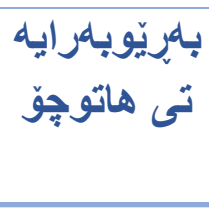 & 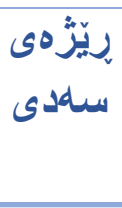 & 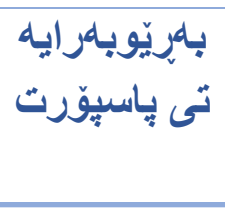 & 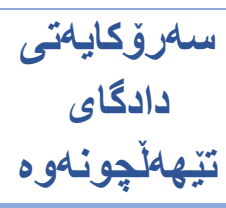 & ريكلامى ياليوهندى \\
\hline$\% \vee 0$ & $r$ & $\%$ ro & 1 & $\cdot$ & \\
\hline$\% 1 \ldots$ & & $\varepsilon$ & & . & كوّى كثنتى \\
\hline
\end{tabular}

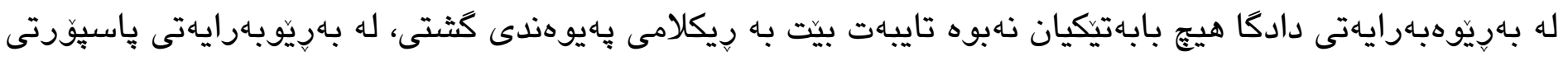

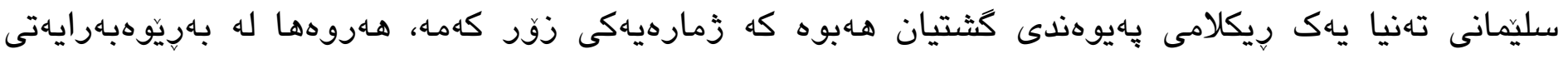

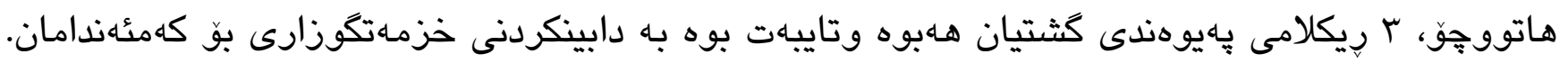


يشت بهاستن بهو ئهنجامانهى كه له شيكارى ناوهرِكى ئهو بابهتانهى كه له ماوهى شهاشه مانكَا شيكار

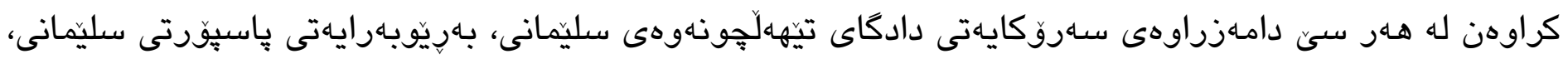

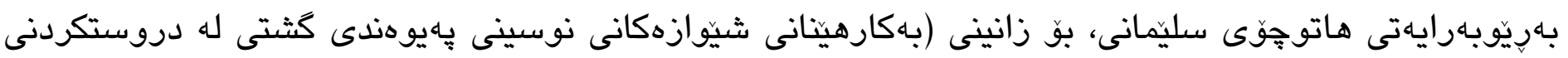

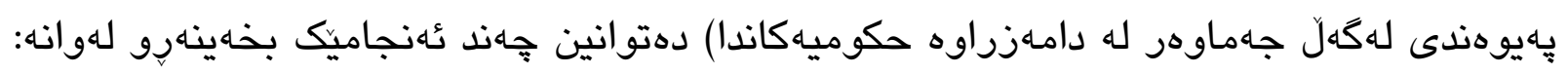

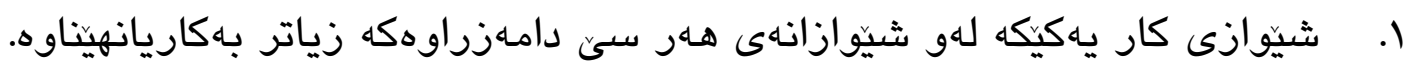

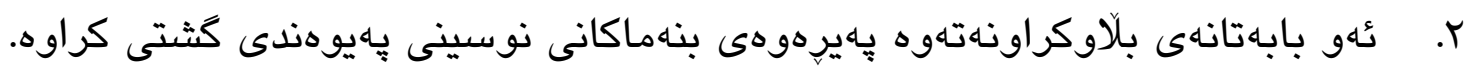

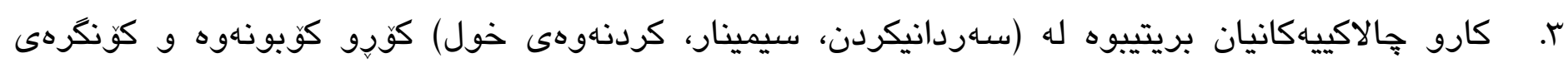
روّزنامهوانيان ئهنجامنهداوه.

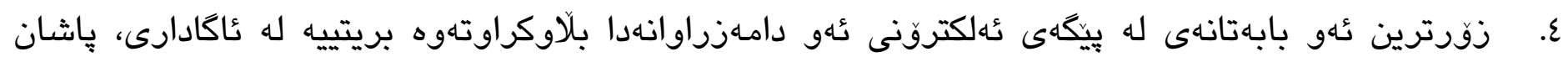

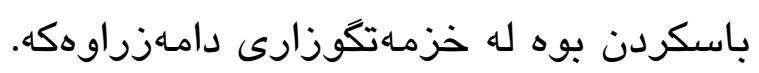

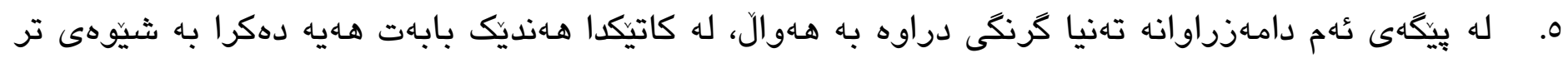

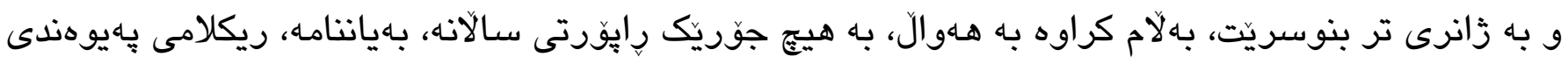

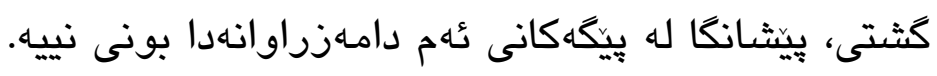




\title{
Forms of Public Communication That are Written to Build Relations Between The Audience and Governmental Institutions: A Case Study of Governmental Institutions' Electronic Sites
}

\section{Shokhan Abubakr Ali}

Media Department, College of Humanities, University of Sulaimani, Sulaimani, Kurdistan Region, Iraq.

E-mail: shokhan.ali@univsul.edu.iq

\begin{abstract}
The electronic site is one of the latest forms of communication facilities that governmental institutions use to establish public relations with their audiences. Governmental institutions utilize a variety of services and initiatives to develop good relationships with their audiences.
\end{abstract}

To bring their work and actions to the majority of the public, they use various forms of mass media. The title of this research (Forms of public communication that are written to build relations between the audience and governmental institutions: a case study of governmental institutions' electronic sites).

The significance of this research has focused on all of the subjects reported on the official websites of governmental institutions, as well as the review of the subjects and all of the aspects to know how to write the subjects and to be aware of all of the activities that the institutions conduct. Thus, all organizations must maintain their main sites and be able to better guide their matters to the public, which is one of the most critical circles of contact between governmental institutions and local and international audiences.

The main question of this study is to determine what type of public relations writing is used, in which area, and what governmental institutions' activities are.

The study aims to demonstrate the most popular writing styles and genres for public relations, as well as to be aware of the principles of writing, and to illustrate the subjects and actions that 
the institution does. Knowing the details and specifics of the topics published on the institution's website is also essential.

This thesis is a descriptive study using the content analysis approach, intending to analyze the subjects of the main site of the governmental institutions in Sulaimaniyah. For this reason, the Directorate of the Sulaimaniyah Appeals Court, the Passport Office of Sulaimaniyah Province, and the Sulaimaniyah Traffic Directorate have set out all matters for six months from December $1, r \cdot 19$ to January $r, r \cdot r \cdot$.

As a consequence, the working style is one of the methods that the three institutions have used most often, and the articles written adhere to the standards of public relations writing. The majority of their activities included (visiting, conferences, courses, gathering) the majority of their publications, and then mentioning the institution's services, which were solely focused on news.

Key worlds: Public Relations, Writing Public Relations, Governmental Institutions, Relationship, Public, Website. 

اصبع، صالح خليل(1990)، الاتصال والاعلام في المجتمعات المعاصرة، عمان: دار ارام للدراسات و النثر والتوزيح.

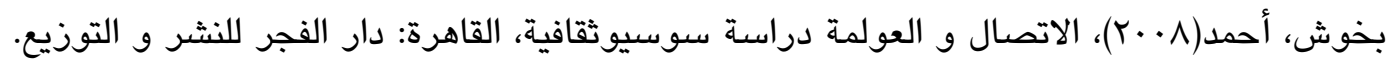

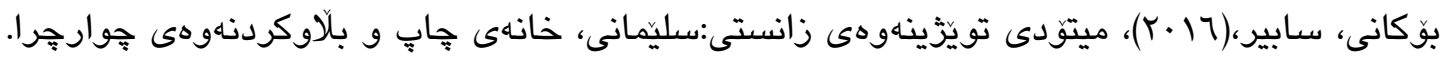

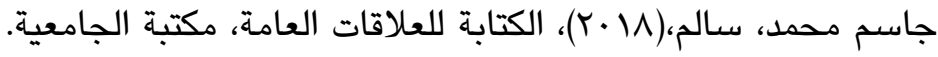
نيوسوم، دوج، كاريل، بوب ،(9.(Y)، الكتابة للعلاقات العامة الثكل والأسلوب، ترجمة: د.فايد رياح، د.مي الخاجة، الطبعة الثانية،الإمارات العربية المتحدة: دار الكتاب الجامعي. سليم، حنان،(r| (Y)، الاتجاهات الحديثة في العلاقات العامة، القاهرة: دار النهضة العربية. الشمري، على جبار،(1) (Y)، الأساليب العلمية في ممارسة العلاقات العامة، القاهرة: العربي للنشر والتوزيع. فريد الصحن، محمد،(ع (Y)، العلاقات العامة المبادئ و التطبيق، الاسكندرية: الدار الجامعية.

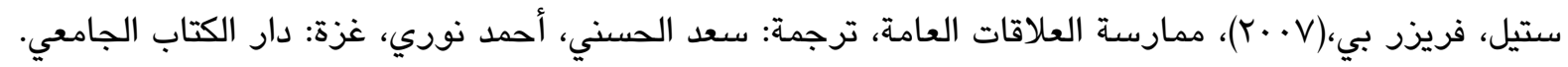

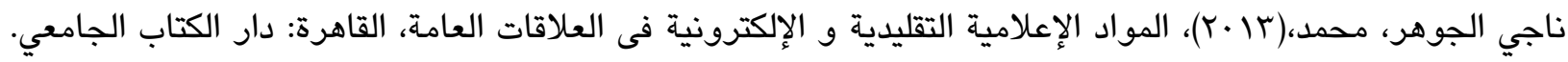
محمد،محد البادى،(N(Y))، فنون العلاقلا العامة، القاهرة: دار النهضة العربية.

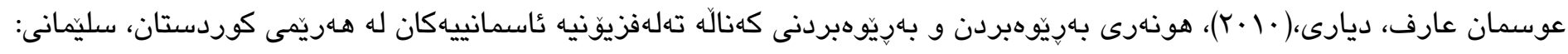

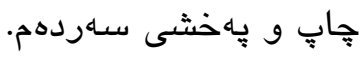

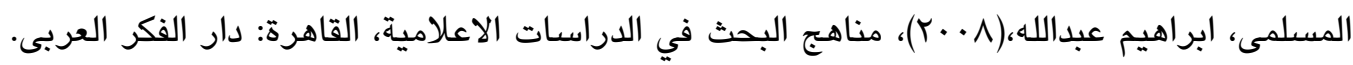

Lefftingwell ‘W and Robinson ‘E( (9^•), Text books of management, new del-hi, Tat Me Graw-Hill book, co.

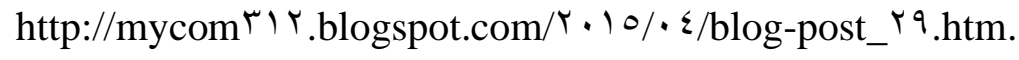

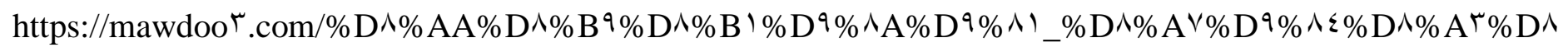
$\% \mathrm{~B} r \% \mathrm{D} q \% \wedge \varepsilon \% \mathrm{D} \% \% \wedge \wedge \% \mathrm{D}^{\wedge} \% \mathrm{~A}^{\wedge}$ 